\title{
Bringing our boy home: \\ The Tomb of the Unknown Warrior, its visitors, and contemporary war remembrance in New Zealand
}

\author{
By \\ Gareth Phipps
}

A thesis submitted to Victoria University of Wellington in partial fulfilment of the requirements for the degree Master of Museum and Heritage Studies

Victoria University of Wellington

2009 


\section{Table of Contents}

$\begin{array}{ll}\text { ACKNOWLEDGEMENTS } & 2\end{array}$

$\begin{array}{ll}\text { ABSTRACT } & 3\end{array}$

$\begin{array}{lr}\text { INTRODUCTION } & 4\end{array}$

$\begin{array}{lr}\text { CHAPTER 1: LITERATURE REVIEW } & 8\end{array}$

$\begin{array}{lr}\text { CHAPTER 2: THE TUW PROJECT } & 20\end{array}$

$\begin{array}{lr}\text { CHAPTER 3: METHODOLOGY } & 28\end{array}$

$\begin{array}{ll}\text { CHAPTER 4: ANALYSIS AND DISCUSSION } & 39\end{array}$

$\begin{array}{ll}\text { APPENDIX 1: THE VISITOR SURVEY } & \mathbf{7 0}\end{array}$

$\begin{array}{ll}\text { APPENDIX 2: NWM VISITOR RESEARCH TIMETABLE } & \mathbf{7 6}\end{array}$

$\begin{array}{ll}\text { APPENDIX 3: INFORMATION SHEET } & 77\end{array}$

$\begin{array}{lr}\text { BIBLIOGRAPHY } & 78\end{array}$ 


\section{Acknowledgments}

The completion of this dissertation has been a journey during which I have incurred numerous debts.

I would like to thank all those visitors to the National War Memorial (NWM) who took the time to participate in my survey. During the course of my research I spent many hours at the NWM and I am grateful to the staff there for their humour and patience. In particular, Paul Riley, for providing access to visitor comment books and teaching me about the nuances of 1960s rock music, and Ashley Mackenzie-White, whose anecdotes kept me entertained during some long waits between visitors.

I would also like to thank my friends and colleagues from the Ministry for Culture and Heritage $(\mathrm{MCH})$ for their support. I am particularly indebted to Brodie Stubbs for providing me with the Tomb of the Unknown Warrior (TUW) project files, Neill Atkinson and Imelda Bargas, who read through drafts of this project and provided helpful suggestions on content and editing, and the rest of the History Group for their encouragement and support.

I would like to thank my supervisor, Lee Davidson, whose guidance and knowledge of the murky world of social research was invaluable, and the staff in the Museum and Heritage Studies programme, whose support has been much appreciated over the last three years.

I would also like to thank my friends and family for their encouragement in this project, in particular Jan, whose cooking ensured I never went hungry, and Mum, whose interest in this project never waived even when mine sometimes did. Finally, this dissertation is for my Dad, who I know would have been extremely proud that I finished what I started. 


\begin{abstract}
In November 2004 the remains of an unknown New Zealand soldier from the First World War were brought home from France and placed in the Tomb of the Unknown Warrior (TUW) outside the National War Memorial (NWM) in Wellington. This was one of the largest ceremonial events ever held in New Zealand, and the entire programme was broadcast live on national television. An estimated 100,000 people lined the streets of Wellington to watch his casket make its way from Parliament to its final resting place. Why did the return of the Unknown Warrior, some 90 years after his death, have such an impact on the country, and what is the significance of the TUW for visitors today?
\end{abstract}

The aim of this dissertation is to bring together the material culture of war commemoration with aspects of public memory and meaning-making in an examination of visitor interpretations of the TUW. To achieve this, entries left in the NWM visitor books and onsite survey interviews are analysed in the light of the institutional objectives set out in the design and planning of the TUW, and the political and popular motivations that led to its construction.

The view advanced by this dissertation is that visitors draw on individual memory, civil remembrance and national commemoration to construct meanings of the TUW. Their interpretations draw on lived experience and personal connections to form connections with the TUW. These are influenced by the impact of 'grassroots' interest in war remembrance, soldier ancestors and an understanding of the experience of war, public ritual and state involvement in commemoration. This provides a snapshot of contemporary war remembrance in New Zealand. 


\section{Introduction}

In November 2004 the remains of an unidentified New Zealand serviceman were brought home from France and placed in the Tomb of the Unknown Warrior (TUW) outside the National War Memorial (NWM) in Wellington. A casualty of the

First World War, the Unknown Warrior represented one of the almost 30,000 New Zealand war dead buried overseas $-9,000$ of whom have no known grave (Shoebridge 2009). On Armistice Day 2004 his remains were interred in a specially constructed tomb at the NWM. The TUW was built to provide a place for the nation to remember and commemorate the sacrifice made by New Zealand servicemen and women. As such, it was designed to be a distinctly New Zealand memorial. According to its designer, Kingsley Baird:

... [The] tomb is an expression of the nation's memory and a crosscultural language of remembrance [that] combines Maori and Pakeha ritual, symbolic, and visual elements...to express remembrance specific to New Zealand's contemporary identity (Baird 2004).

The return of the Unknown Warrior was a significant event for New Zealand. An estimated 100,000 people lined the streets of Wellington to watch his casket make its way from Parliament to its final resting place, and the ceremonial programme was broadcast live on national television.

In 2007 I read a magazine article in which historian Jock Phillips talked about the history of Anzac Day and its continued significance to New Zealand society (Barry 2007). While uncertain about the specific reasons for the renaissance of Anzac Day in New Zealand, Phillips did suggest that the nature of cultural nationalism that had emerged in New Zealand over the last fifteen years had inspired a general interest in our war history. This link was based on the popular mythology that the First World War created our national identity. Fascination with the First World War remained strong because it an experience totally foreign to most New Zealanders yet still part of our identity, family myths and social rituals. This article started me thinking about 
the nature of contemporary war remembrance in New Zealand, especially how it was represented in material form. During research for an essay on the historiography of New Zealand war memorials and national identity I became aware that there was an abundance of literature on European war memorials, especially those constructed in the aftermath of the First World War. Conversely, very little had been written about war memorials in New Zealand and contemporary memorialising had been virtually ignored. These omissions represented a significant gap in literature. In response I decided to focus my dissertation on the nature of war memory and commemoration in modern-day New Zealand. In particular, I wanted to explore the meanings associated with contemporary war memorials and how audiences interpret these objects.

The broad aim of this dissertation is to bring together the material culture of war commemoration with aspects of public memory and interpretation in order to provide a snapshot of the state of war remembrance in modern-day New Zealand. I intend to do this by exploring the features of war memory represented by the Unknown Warrior and the TUW alongside the interpretations of visitors to the memorial. In particular, I look at the social, cultural and political motivations that shaped the TUW project and use visitor research methods to explore how people interpret and construct meanings during visits to the site. I decided to use the TUW as my case study for two main reasons. First, as a recent memorial built in 2004 it reflected contemporary priorities, politics, and sensibilities. Second, the TUW's location at the NWM in Wellington made it accessible enough to undertake visitor research onsite.

This dissertation is divided into four chapters. Chapter 1 frames the TUW project against a background of literature related to war memory and commemoration. I set the scene by examining the increased public interest in war memory and practices of war commemoration, including the study of war memorials in Europe, Australia and New Zealand. I then explore the main theoretical paradigms that have shaped literature on this subject. This includes political literature, which associates war commemoration with the creation of national identity and maintenance 
of hegemony by social elites; and work that moves beyond broad nationalistic templates to examine the impact of human agency on war memorialising. I also investigate a third paradigm of war memory scholarship that draws on aspects of oral history and life history narratives to examine the impact of individual subjectivity on the construction of war memory narratives. In the following section I locate the TUW project against a background of contemporary war memorialising. I consider developments in the nature of modern warfare and memorial culture, before looking at the state of popular war remembrance in Australia and New Zealand. I conclude this chapter by looking at the benefit of the TUW as a case study and the use of public history and visitor research studies ideas and methods to frame interpretive research into visitor experience at this memorial.

In Chapter 2 I look at the planning and construction of the TUW memorial. I start by outlining previous campaigns to repatriate a New Zealand Unknown Warrior, before moving on to explore the themes and messages associated with the project, the controversy surrounding the TUW's initial design, and the popular reception to the return and interment of the Unknown Warrior.

Chapter 3 begins by outlining the qualitative research methodology I used during my dissertation. I summarise the constructivist, interpretivist, and phenomenological paradigms that informed my research model, and examine their relevance to my research methods. I examine the use of visitor books and surveys as research methods, highlighting the advantages of both methods and their application by researchers studying visitors at heritage sites. I consider issues related to site selection, research population, and the data gathering process. Finally, I clearly specify the boundaries of my research at the NWM and outline the procedures I followed to maintain ethical research practice.

In Chapter 4 I analyse the findings of my visitor research and discuss some of the significant trends and themes that have emerged. I begin by looking at the NWM visitor book entries. I outline the gender and nationality characteristics of visitors in 
each sample, as well as some of the different types of visitors making entries. Next I explain the process of grounded thematic coding I used to categorise the visitor comments in terms of place; remembrance; the Unknown Warrior; thanks and gratitude; personal connection; condolence; peace; nationalism; and the inability or refusal to comment. I then move on to consider these themes by analysing and discussing related entries drawn from the NWM visitor books. In the final section I look at how survey respondents employ a combination of collective national narrative and personal experience to form interpretations of the TUW.

Finally, I examine the conclusions drawn from my research. These show how visitors to the TUW are influenced by a mixture of national narrative and personal experience built around public ritual, national identity, and personal connections. I suggest that this visitor interpretation takes place against the backdrop of a contemporary war narrative that emphasises the uniqueness of New Zealand's shared bi-cultural experience but omits more problematic aspects of our war history. 


\section{Chapter 1: Literature Review}

In this chapter I frame the TUW project against a background of literature related to war memory and commemoration. I set the scene by examining the increased public interest in war memory and practices of war commemoration, including the study of war memorials in Europe, Australia and New Zealand. I then move on to explore the main theoretical paradigms that have shaped literature on this subject. I consider political literature that associates war commemoration with the creation of national identity and maintenance of hegemony by social elites, as well as work concerned with the human agency involved in war memorialising, which moves beyond broad nationalistic templates to examine issues of sorrow and grief. Both paradigms are explored in relation to the mass memorialising that occurred in the aftermath of the First World War, when the burial of unknown soldiers became common practice. I finish this section by investigating a third paradigm of war memory scholarship that draws on aspects of oral history and life history narratives to examine the impact of individual subjectivity on the construction of war memory narratives. In the following section I locate the TUW project against a background of contemporary war memorialising. I consider developments in the nature of modern warfare and memorial culture, before looking at the state of popular war remembrance in Australia and New Zealand. I conclude this chapter by looking at the benefit of the TUW as a case study and the use of public history and visitor research studies ideas and methods to frame interpretive research into visitor experiences at this memorial.

At this point it should be noted that I have limited my discussion in this chapter to literature related to the field of war memory and commemoration. Due to the tight scope of the project I have not reviewed more general works on the nature of collective memory (Halbwachs 1992) and the relationship between memory and heritage (Nora and Kritzman 1996-98; Lowenthal 1985). While these works touch on aspects of memorialisation the concepts they discuss have been thoroughly critiqued and fall outside the central focus of this project. 


\section{War memory and commemoration}

Over the last three decades there has been a considerable increase of public interest in war memory, and in the various forms and practices of war commemoration. Worldwide, this trend has been characterised by the proliferation of high-profile anniversaries commemorating key events of the world wars; increased interest in capturing the memories of veteran generations as they age and disappear; and the emergence of the Holocaust and its survivors into public consciousness (Ashplant, Dawson, and Roper 2004).

Public interest in war memory has been accompanied by a proliferation of studies on the cultural legacy of war (Ashplant, Dawson, and Roper 2004). Since the 1970s a range of interdisciplinary studies have explored war memorials, trench literature, battlefield pilgrimages and a host of other representations and signifying practices in the aftermath of military conflict (Fussell 1975; Borg 1991; Lloyd 1998). This wave of war memory scholarship has opened up new areas of inquiry into the remembrance of the Holocaust (Young 1993) and the Vietnam War (Hass 1998), while the study of war memory has become an established element in various national historiographies (Sherman 1999; Damousi 2001).

In New Zealand, war memory and commemoration have been subjects of increasing curiosity. According to Jock Phillips (2005) the 'rediscovery' of New Zealand's war memory began during the 1980s with oral history interviews of the last remaining Gallipoli and other First World War veterans by Maurice Shadbolt (1988), and Nicholas Boyack and Jane Tolerton (1990). Over the last decade publications dedicated to the memory and commemoration of war have continued to grow. Oral history projects have recorded the experiences of New Zealanders during the Second World War and Vietnam War (Challinor 1998; Atkinson 2005; Hutching 2001, 2002, 2004, 2005, 2006, 2007), while work by Scott Worthy (2004) on the 'communities of remembrance' involved in the building of the Auckland War Memorial Museum and 
Sandy Callister's (2008) study of war photography and memorialising have gone some way to broadening war remembrance discourse within New Zealand.

One of the most popular areas of study within this wave of war memory scholarship has been the war memorial. Over the past two decades a number of studies have explored the building of war memorials and their intended purpose. There have been several significant studies of British and European war memorialising and commemoration in the immediate aftermath of the First World War (Mosse 1990; Winter 1995; King 1998). In New Zealand and Australia, Chris Maclean and Jock Phillips (1990) and Ken Inglis (1998) have produced fine surveys which chart the respective histories of war memorials within each country, from early colonial wars and conflicts through to the Vietnam War. Two distinct frameworks of war memory and commemoration theory have influenced the bulk of this war memorial literature.

\section{Politics, psychology and popular memory}

War memory and commemoration have traditionally been studied within two distinct political and psychological paradigms (Ashplant, Dawson, and Roper 2004). The political paradigm has focused on war commemoration as a basis for creating collective national identity, while the psychological approach has looked at war commemoration as a basic response to mass death.

Proponents of the political paradigm have viewed war commemoration and its material representation(s) as a means of creating and maintaining collective national identity. Eric Hobsbawm and Terence Ranger (1983) looked at the role played by memorials in constructing versions of the past, and the continuity of the past and present in establishing social cohesion, legitimising authority and socialising people into a common culture. Similarly, Raphael Samuel (1994) identified memorialising as a part of the master narratives that elite supporters of the nation state impose from top-down to consolidate control of their citizenry. Benedict Anderson (1991) 
described the nation as a collective defined by its own ways of imagining itself and the identity of those who belonged to it. War memorials were classic representations of such imaginings - they helped evoke the notion of sacrifice that may be required from citizens as a cost of belonging, and presented the means by which the nationstate persuaded its citizens to die for it (Anderson 1991).

For those interested in the political aspects of war commemoration the First World War was a watershed moment. In the aftermath of the First World War commemoration of the dead was used to confirm and circulate political ideas about the war and the nations that participated. According to George Mosse (1990) war memorials played a particularly important role in preserving the image and continuing appeal of the nation. By listing the names of war dead on surrogate graves the horror and trauma of war was buried and the meaning of death reinvested as collective sacrifice (Winter 1995). This way the state, individual mourners, and veterans were all able to give meaning to the war and the losses they had suffered (King 1998).

To facilitate this process a new democratic style of war memorial emerged, in which iconography moved from the commemoration of generals or rulers to the acknowledgement of ordinary soldiers (Mosse 1990). This was epitomised by the burying of an unknown soldier in Westminster Abbey in London and under the Arc de Triomphe in Paris following the First World War. The entombing of unknown soldiers in national shrines was a result of the development of what George Mosse called the 'cult of the fallen soldier' - a collective belief that the sacrifice and commemoration of ordinary soldiers was the ideal of any national community (Mosse 1990). The cult used unknown soldiers to represent the sacrifice of the rank and file in Europe and beyond - war memorials employed iconography valid for all soldiers while the presence of actual martyrs created effective places of pilgrimage for the nation (Mosse 1990). 
Writing at the beginning of the 1990s Mosse predicted that the cult of the fallen (war dead) would not survive the pressures of modern society. The course of nationalism, illustrated by the collapse of the Soviet Union, and emergence of the European Union seemed destined to relegate the cult into history (Mosse 1990). Nearly two decades later, memorials to unknown soldiers continue to be created. In 1993 Australia repatriated the remains of a man who died in the First World War and interred them in a tomb at the Australian War Memorial, while similar projects were carried out by Canada in 2000 and of course New Zealand in 2004.

Advocates of the psychological approach to war memory and commemoration have criticised the work of scholars such as Hobsbawm, Anderson and Mosse for overemphasising the political meanings of war remembrance and failing to acknowledge the importance of human agency in commemoration (Winter 1995). Jay Winter (1995) states that public mourning was the catalyst for memorialising the dead in Europe following the First World War. This process, he argues, was not driven by the nation state but stimulated by a human desire for psychological compensation in response to the traumatic death of friends and family in war. In this environment, the initial task of war memorials was to satisfy the grief of a huge population of bereaved (Winter 1995). War memorials gave grieving families a public place to mourn, and provided a focus for the rituals, rhetoric, and ceremonies of bereavement (Ashplant, Dawson, and Roper 2004).

Despite the traditional dominance of both political and psychological paradigms recent studies have begun to question the validity of such mutually exclusive approaches to the study of war memory and commemoration. Ashplant, Dawson and Roper (2004) have insisted that the emphasis on politics (Hobsbawm and Ranger 1983; Anderson 1991; Mosse 1990) or on death or suffering (Winter 1995; Winter and Sivan 1999) obscures the complicated relations involved in war memory, especially between individual memory, remembrance in civil society and the national commemorative practices of the state. Both approaches tend to ignore individual subjectivity, under-conceptualising the richness and complexity of 
personal memory and the extent to which it is constructed through practices of commemoration at local and state level (Ashplant, Dawson, and Roper 2004). Ashplant, Dawson and Roper (2004) argue that a more integrated account of the processes that link the individual, civil society and the state can be found in a third body of work on war memory that uses oral-history and life-story methods.

The life-story paradigm considers the meanings about war and remembrance that people make for them and express in their own words and stories. Researchers working within the life-story paradigm have been heavily influenced by the studies done in the early 1980s by the Popular Memory Group (PMG) at the Centre for Contemporary Studies in Birmingham, England. The central premise of the PMG's work is the distinction between private and public memory, and the ways they interact in the construction of 'popular-memory' (Misztal 2003). The interaction between private and public memory is understood as a hegemonic process of ideological domination and resistance (Green 2004). In other words, the act of remembering always invokes broader public discourses - personal accounts of the past are never produced in isolation from public narratives, including the nation state (Thomson 1994).

One of the best examples of the popular-memory approach is Alistair Thomson's Anzac Memories (Ashplant, Dawson, and Roper 2004). Based on oralhistory interviews with First World War veterans, Thomson looked at how various forms of public and private remembering constructed the Anzac legend in Australia (Ashplant, Dawson, and Roper 2004). The formation of this public legend was analysed as a process of historical contestation involving a variety of agents, including official war historians, returned servicemen's groups, film-makers, antiAnzac Day feminist protesters, oral historians and elderly veterans of the 1980s (Ashplant, Dawson, and Roper 2004). According to Thomson, the private memories of the veterans shifted in relation to the changing forms and meanings of the public legend, and the identities of the men themselves at different stages in their life course (Thomson 1994). Connections between individual subjectivity and the construction of 
war memory can be explored further by looking at the negotiations and developments involved in contemporary war commemoration.

\section{Contemporary war commemoration}

Over the last three decades modern war memorialising has taken place in what Martin Shaw (1997) calls a 'post-military society'. The participatory mass-militarism that defined the world wars has been replaced by a culture of the weapon. According to Shaw mass media has transformed modern warfare into another element of consumer culture - a spectator sport enjoyed from the safety of people's living rooms (Shaw 1997). The narrative of nation building, which defined post-First World War memorialising, has also been challenged by recent historical developments. Events such the collapse of the Soviet Union and the creation of the European Union challenged the hegemony of territoriality, and subsequently altered the nature of warfare. Winter and Prost (2005) argue that wars are no longer seen as confrontations between sovereign nation-states. The emergence of organised violence and advent of the 'war on terrorism' has seen recognised states in conflict with small groups of men and women acting outside the boundaries of state politics (Marshall 2004).

Debra Marshall (2004) believes such changes in the nature of war have provided the opportunity for different stories to emerge out of memorials to past wars. As war history has been re-examined omissions and discoveries have been made, opening up the way for re-interpreted readings of these sites and the emergence of new narratives (Nathan 2008). An example of this is the Blackball war memorial on the West Coast of New Zealand. Unveiled in March 2008, during centenary commemorations of the 1908 Blackball mine strike, the war memorial represented a significant re-evaluation of local history. As a socialist stronghold, strong anti-war feelings had prevented a war memorial being built at Blackball after either world war. A century later Blackball was a much different community. The area was no longer dominated by the mining industry and the trade union movement - and local residents endorsed the war memorial project. 
Within this re-interpretation of war commemoration new types of memorials have emerged. James Young (1993) has explored the rise of 'counter memorials' to the Holocaust in Germany. Examples such as the Harburg Monument against Fascism and the Invisible Monument in Saarbrücken were the antithesis of traditional war memorial design. Built into the ground and designed to disappear instead of standing for all time they returned the burden of memory to the visitors. ${ }^{1}$ One of the most famous counter memorials outside Europe is the Vietnam Veterans Memorial in Washington DC. The memorial is comprised of two V-shaped intersecting black granite walls inscribed with the names of 58,175 American dead and missing from the Vietnam War. Designed as an opening or wound in the earth to symbolise the loss of the soldiers, the memorial caused controversy because it avoided traditional heroic imagery and did not allow individual deaths to be subsumed within a national narrative.

Some scholars believe the degree of contestation in contemporary war remembrance has been over-emphasised. Remarking on the nature of war commemoration in Australia at the end of the twentieth century, Ken Inglis (1998) argues that increased attendances on Anzac Day, government subsidies for memorial restoration projects, and the 'new' Unknown Soldier of 1993 were the result of a decline in the contested nature of war remembrance. Stephen Clarke (2008) identifies a similar lack of public contestation within New Zealand war remembrance. While war and national security issues have largely diminished in New Zealand society since the Vietnam War and the thawing of the Cold War, there has been a steady increase in 'grassroots' support for war remembrance (Clarke 2008). This popular support has been accompanied by an increased presence of New Zealand history in the school curriculum and public history, as well as a growth of interest in genealogy and the search for soldier ancestors. The state has re-entered the remembrance arena

\footnotetext{
${ }^{1}$ Artist Jochen Gerz built both memorials. The Harburg Monument was a 12-metre tall square column engraved with the signatures of the city's residents and visitors. The column was lowered eight times between 1986 and 1993 until it disappeared from view. The Saarbrücken Monument saw paving stones in front of the Saarbrücken Castle removed and replaced with ones bearing the names of Jewish cemeteries used in Germany prior to the Second World War. These stones were placed with the inscription facing the ground.
} 
on the back of this wave of public enthusiasm, and memorial projects such as the TUW have been undertaken in the name of nation-building and national identity (Clarke 2008).

While war commemoration has been one of the cornerstones of the development of national identity in Australia and New Zealand, the narrative of nationalism it promotes has been criticised for its inconsistencies and omissions. Liz Reed (2004) underlines the fact that war memorialising in Australia remains the exclusive preserve of the male white Australian. The problematic nature of incorporating the Aboriginal story within the Anzac mythology, especially given the debate surrounding the issue of 'frontier' warfare between white settlers and Aborigines has seen the indigenous story subsumed within the Australian 'digger' narrative (Reed 2004). In New Zealand, bi-cultural elements of remembrance have become integral parts of recent memorial projects (Hunter 2002). Māori symbolism was incorporated into the design of high-profile New Zealand memorials in Canberra in 2001 and London in 2006, while cultural elements were included in the ceremonial service for each project. While this pluralism may seem democratic and inclusive, Rachel Buchanan (2007) argues that New Zealand's war memorialising also continues to ignore or marginalise parts of its war history - most notably the internal New Zealand Wars of the nineteenth century. ${ }^{2}$ Focusing on the recently completed TUW Buchanan writes:

...what is clearly troubling about the memorial - to me at least - is the way this overtly bicultural tomb ignores New Zealand's wars of foundation...Memories of these complicated foundational wars, including war stories associated with the site on which the tomb has been built, nibble away at this elegant new memorial, diminishing its mana (status) and power (Buchanan 2007, 179-180).

For Buchanan, the absence of any reference to the New Zealand Wars at the TUW or NWM in general suggest that these wars have disappeared from the centre of

${ }^{2}$ The New Zealand Wars 1843-1875 were a series of armed conflicts fought between Māori and British imperial forces, settler militia, and their Māori allies. The wars were fought over a number of issues, most notably Māori land being sold to the (white) settler population. 
national collective memory (Buchanan 2007). Comments such as these raise interesting questions regarding the interpretation of war memorials within New

Zealand - just whose sacrifice is (or is not) being memorialised in projects such as the TUW, and how is this interpreted by visitors to these sites?

\section{Dissertation framework}

The TUW provides an ideal case study around which I explore the significance of war memory in New Zealand. As a memorial of national significance the TUW incorporates elements of the political and psychological paradigms identified in work on war memory and commemoration. On one level the construction and design of the TUW reflect contemporary social, cultural and political sensibilities, while the presence of the Unknown Warrior provides a focus for the grief of families who are unable to access the graves of relatives buried overseas. The fact that the TUW is such a recent addition to the NWM provides the opportunity to explore how visitors interpret and construct meaning from such a contemporary memorial.

In looking at subjective experience of war memory and commemoration my dissertation draws on elements of public history and visitor studies research. Public history is an ideal methodology with which to investigate the ways that people communicate and interpret representations of history in public. According to David Glassberg (1996) new scholarship on the study of memory has incorporated public history ideas and methods to examine the thinking of audiences where multiple versions of the past converge and are understood. Whereas earlier approaches had assumed that audiences more or less understood historical images the same way, new approaches emphasise the various interpretations audiences derive from the same historical representation (Glassberg 1996). This interpretation suggests that the meaning of a memorial like the TUW is not intrinsic but changes as audiences actively reinterpret what they experience according to their personal experiences and social backgrounds. 
This change of interpretation has been mirrored in the field of museum visitor studies. According to Sharon Macdonald (2006) museum professionals have realised their audiences are far more diverse and active in their learning than previously thought. The traditional 'transmission' model of communication employed by museum educators, in which visitors were expected to absorb and retain information transmitted by the museum 'expert', has been re-evaluated over the last three decades as museum professionals discovered not all visitors were inclined to achieve the educational goals set for them (Macdonald 2006). This acknowledgment of the 'active' agency of audiences has redefined the museum space. Museums are no longer attempting to tell a single national narrative through their collections but multiple stories. James Clifford (1997) argues that museums have developed into 'contact zones' in which ideas are exchanged, interpreted and negotiated between two or more worlds. In other words, the museum has become a site where ideas are negotiated by a diverse audience rather than just merely produced and received by a homogenous collective.

Elements of both public history and museum visitor research studies can be extended and reconfigured for the study of the TUW and its visitors. David Glassberg (1996) suggests that visitor research helps public history scholarship move beyond merely looking at historical objects, such as war memorials, for a range of possible readings and allows the researcher to discover what meanings surface in a particular historical situation. In this dissertation, I employed an interpretive research methodology, which acknowledged the active character of the individual and the social construction of meaning.

\section{Contribution and significance}

In focusing on the subjective element of war remembrance this dissertation opens up fresh areas of inquiry in the field of war memory and commemoration in New Zealand. As discussed earlier in this chapter, historiography on this subject has traditionally emphasised the political (Mosse 1990; Anderson 1991) and human- 
agency (Winter 1995) elements of war memorialising. Much of this literature has focused on the production and function of war memorials in the aftermath of the world wars of the twentieth century (King 1998; Lloyd 1998). While these studies inform us of the processes which led to the building of war memorials they cannot shed light on the individual responses of those who visited them at the time of their unveiling. The First World War generation of veterans and bereaved families have disappeared, while the numbers of Second World War eyewitnesses are thinning rapidly. The significance of this dissertation is its attempt to capture the subjectivity of the commemorative experience and explore the connections between individual and public memory.

By looking at the reactions of New Zealand (and international) visitors to the TUW my research is also contributing to literature on the nature of contemporary war commemoration, which includes the pioneering work of Alistair Thomson (1994) and Bruce Scates (2006). Scates investigation of personal pilgrimages to the First World War battlefields of Gallipoli and the Western Front is one of the first attempts to record visitors' own accounts of their experiences. In what he termed a 'participant history' Scates used visitor surveys and interviews to trace the experience of 700 Australian and New Zealand pilgrims at various sites of significance in Turkey and France (Scates 2006). Through this visitor research he discovered that these modern day pilgrims were motivated and influenced, to varying degrees, by emotion, memory, family (history), and national history. By incorporating elements of public history and museum visitor research into my study this dissertation will provide a similar glimpse into the types of present day visitors making 'pilgrimages' to the TUW and the factors that shape their interpretation of this national memorial. Before I move on to this interpretive analysis some background about the TUW is needed. The following chapter looks at the TUW project history, outlines the themes and messages associated with this national memorial project, and explains how the placement and design of the TUW was shaped by institutional negotiation. 


\section{Chapter 2: The TUW Project}

In this chapter I look at the Government-led project to return New Zealand's Unknown Warrior. I start by outlining previous campaigns to repatriate a New Zealand Unknown Warrior, before moving onto to examine the TUW project in detail. This includes the themes and messages associated with the project, the controversy surrounding the TUW's initial design, and the popular reception to the return and interment of the Unknown Warrior.

\section{Early beginnings}

On 11 November 1920 Britain re-interred the remains of an unknown soldier in Westminster Abbey in London as a memorial to the First World War dead of the British Empire - of which New Zealand was a part. A year later the idea of repatriating the remains of an unknown New Zealand serviceman was raised. On Armistice Day 1921 the Member of Parliament for Waitomo, William Jennings asked Prime Minister William Massey whether cabinet would consider bringing home the remains '... of one of our unknown boys' (Hon. William Jennings 1921). After some deliberation cabinet decided not to proceed with the idea, presumably because of the financial costs involved and the existence of the Westminster tomb (Schouten 2004).

The idea resurfaced again after the Second World War as part of an unsuccessful New Zealand Returned Services Association (NZRSA) campaign to secure completion of the NWM. Up to this point this memorial had been a piece-meal affair. Plans to build a NWM in Wellington had initially begun in 1919 but took thirteen years to complete (Shoebridge 2009). During this period there were numerous suggestions on what form the memorial should take but the Government finally decided on building a 50-metre memorial Carillon tower. ${ }^{3}$ The Carillon was to be the central feature of a complex of buildings, which would include a national art

\footnotetext{
${ }^{3}$ A Carillon is a musical instrument consisting of at least 23 bells tuned chromatically to create a harmonious effect. At present, the Carillon at the NWM has 74 bells, which makes it the third-largest in the world.
} 
gallery and national museum (Shoebridge 2009). The site chosen for the new NWM was Mount Cook, a prominent hill that could be seen from many parts of the city. The Carillon was opened on Anzac Day 1932 in front of a crowd of 10,000, while the National Art Gallery and Dominion Museum (predecessor to the Museum of New Zealand Te Papa Tongarewa) were formally opened in August 1936 (Shoebridge 2009). Although architects had planned to include a Hall of Memories adjoining the Carillon to serve as a commemorative chapel, the Great Depression of the 1930s and

the outbreak of the Second World War forced the postponement of this addition. In 1950 the NZRSA submitted a proposal to the Government outlining their plans for the development of the NWM. These included provisions for the construction of tombs of two Unknown Warriors from each world war (Kippenberger 1950). The cost of the NZRSA proposal, an estimated $£ 250,000$, proved prohibitive though and development of the NWM stalled until the Hall of Memories was completed in 1964 (Kippenberger 1950).

\section{Government support}

Fifty years passed before the idea of a New Zealand Unknown Warrior was broached again. In 1999 military historian Ian McGibbon recommended that the Department of Internal Affairs investigate the possibility of repatriating the remains of a New Zealand unknown soldier as a high-profile millennium project. Highlighting the unveiling of Australia's Tomb of the Unknown Soldier in 1993, McGibbon believed the return of a unknown New Zealand soldier would be '.... a visible and dramatic way of honouring and remembering the nation's war dead' (McGibbon 1999). McGibbon brought up the idea again two years later at the launch of his guide to New Zealand battlefields on the Western Front (McGibbon 2001). This time the idea gained traction with Prime Minister Helen Clark, who was among the audience that night, reacting enthusiastically to the suggestion.

In December 2001 the Ministry for Culture and Heritage (MCH) forwarded a preliminary paper to her as Minister for Arts, Culture and Heritage seeking approval 
to develop a proposal for the institution of a TUW in New Zealand. MCH staff made reference to the precedents set by Australia and Canada, and the inference in both projects that the British Tomb of the Unknown Warrior could no longer represent either country's war dead. By following their lead New Zealand would be making its own symbolic statement and providing a focus of remembrance of the sacrifice of New Zealand people in overseas conflicts and peacekeeping missions. More practically, a TUW would provide an accessible symbolic grave at hand for families who had relatives buried in war cemeteries overseas (Matthews 2001).

By early 2002, the Prime Minister had approved MCH to proceed with consultation and preparation of a budget for a TUW project (Matthews 2002). At this stage the project was still in its infancy and the Government had made no firm commitment. This changed on the eve of Anzac Day 2002. The National Party released a media statement outlining their Veteran Affairs policy, in which they indicated their intention to establish a Tomb of the Unknown Soldier. In response, the Minister for Veteran Affairs stated that the Government also intended to establish a tomb and was already working on such a project.

A TUW project team was soon formed along the lines of the Canadian template established for the return of their Unknown Soldier in 2000. The TUW project was to be led by $\mathrm{MCH}$ with a co-ordinating committee made up of representatives from various government departments and external organisations. ${ }^{4}$ One of the first tasks of the TUW project team was to develop a media strategy in order to publicise the key messages and themes of the project.

\footnotetext{
${ }^{4}$ The TUW co-ordinating committee included representatives from the New Zealand Defence Force, Veterans' Affairs New Zealand, Department of Internal Affairs (Visits and Ceremonial Office), Te Puni Kokiri/Ministry of Māori Development, Department of Prime Minister and Cabinet, and the Ministry of Foreign Affairs and Trade; and non-government organisations such as the National War Memorial Advisory Council, the New Zealand Historic Places Trust, Royal New Zealand Returned Services' Association, Te Ati Awa (represented by the Wellington Tenths Trust), and the Wellington City Council.
} 


\section{Project themes and messages}

The key themes and messages of the TUW project were projected through four major points - Tomb, Unknown Warrior, Design, and Project. The idea of nationalism and national identity were a prominent theme in each of these. The Tomb was seen as a national focus of remembrance of those who sacrificed their lives in service for New Zealand. It was described as a symbol of unity and national identity, which would link all generations of New Zealanders and provide a place for war veterans to pay tribute to their comrades.

As for the Unknown Warrior, MCH wanted to emphasise the idea that he was coming home. He was, first and foremost, a New Zealander and his remains represented and honoured all New Zealanders who were lost to their families through war. The fact that his identity was unknown meant that he could symbolically represent all New Zealand war dead, regardless of ethnicity or religion.

In terms of design, the Tomb was to be a distinctively New Zealand memorial, incorporating symbols, language, and material choices that reflected our national identity. Finally, MCH publicised the repatriation of the Unknown Warrior as a once-in-a-lifetime event of prime historical and heritage significance. The decision to construct a TUW was not an attempt to glorify war but to create a contemplative place of remembrance. Most importantly, $\mathrm{MCH}$ stressed that there was no political agenda behind the TUW project and it was an event for all the country to share in (Ministry for Culture and Heritage 2003).

\section{Controversy}

In December 2002 expressions of interest for the TUW design were called. Applicants were asked to submit a tomb design that would provide a suitable resting place for an unknown New Zealand soldier; a fitting memorial to all New Zealand men and women who have lost their lives in war; a peaceful place for contemplation 
and reflection; and a clear reminder to all New Zealanders of those who died in war serving the ideals and interests of New Zealand. The form of the tomb and messages imparted should be timeless and in no way suggest a glorification of war (Ministry for Culture and Heritage 2003).

The winning design was submitted by Robert Jahnke, an established sculptor with work commissioned throughout the country. ${ }^{5}$ Jahnke's design was a pyramidshaped Tomb, which alluded to both the outstretched arms of a whare tupuna (ancestral meeting house) and upright waka (canoe) hull - used in Māori custom to signify the passing of a person of great mana (authority, influence and efficacy). This design was, however, predicated on a redesign of the NWM forecourt and steps, which would see the demolition and replacement of an original staircase, pool and walls. In addition, new disabled access would require the removal of a number of 70 year-old Pohutukawa trees.

The Jahnke tomb soon attracted the criticism of interest groups concerned at the invasiveness of the design. Among the most vocal were members of the Professional Historians Association of New Zealand/Aotearoa (PHANZA) - an organisation made up of history and heritage professionals working in the public and private sector. PHANZA believed that the removal of the formal entrance of the NWM constituted a major irreversible alteration to a place of great national significance. After writing to the Prime Minister and MCH, PHANZA published an article in their April 2003 Phanzine newsletter, highlighting the organisation's concerns about the proposed changes to the NWM and the role of heritage organisations such as MCH and New Zealand Historic Places Trust (NZHPT) in approving such an invasive design (Nightingale 2003). National media outlets picked up on the article and the issue gained some publicity (Milne 2003).

\footnotetext{
${ }^{5}$ Professor Robert Jahnke is now Head of Māori Studies at Massey University. Examples of his artwork stand at Te Papa, Sky City Casino, Wellington High Court, and Taharora Marae in Waipiro Bay.
} 
More tangible signs of protest followed. On Anzac Day 2003 posters campaigning against the renovation of the forecourt were plastered on the steps and forecourt at the NWM prior to the televised Anzac Day service. ${ }^{6}$ Despite the negative media coverage $\mathrm{MCH}$ pushed ahead with the TUW project. According to the Wellington City Council (WCC) heritage listing for the NWM the steps and forecourt were not part of the memorial, despite the fact that they had been built at the same time as the Carillon in 1931-1932 (Butterworth 2003). The MCH, supported by the NZHPT and other project stakeholders, was happy with this interpretation and by May 2003 construction of the TUW was ready to begin. By this stage the only recourse left for opponents was legal action.

PHANZA had no interest in pursuing legal action. Although some of their members felt strongly about the issue the executive decided that the organisation itself had no mandate to commit members or their funds to legal proceedings (Butterworth 2003). This decision was also influenced by the fact that any litigation would involve $\mathrm{MCH}$, which had been a generous supporter of PHANZA and employed several of its members. Instead, a variety of interested parties, including some PHANZA members, formed the Serious About Heritage Society (SAHS). SAHS engaged the services of a resource management lawyer and lodged an appeal in the High Court against the WWC's decision not to include the NWM steps and forecourt in the heritage listing (Butterworth 2003). The appeal was successful and the resource consent for the TUW project was overturned. $\mathrm{MCH}$ was forced to submit a new application and project completion was delayed till November 2004.

The court decision prompted an official change in attitude toward the treatment of the NWM. Whereas the original TUW design had arisen from a desire to give the memorial a higher profile and presence, $\mathrm{MCH}$ now focused on finding a more restrained design. Consultation was far more rigorous as well. A new

\footnotetext{
${ }^{6}$ On the posters was written: "Lest we forget our Heritage - Historic Places Trust Category 1 steps/70yr old Pohutukawa trees will be unnecessarily demolished next month by order of Minister for Arts Culture and Heritage, Prime Minister Helen Clark. Please write to Helen Clark now." All posters were removed before the Anzac service began.
} 
conservation plan for the NWM was commissioned and options for the tomb were peer-reviewed by external organisations such as PHANZA, the New Zealand Institute of Architects, and SAHS before a new resource consent application was submitted (Matthews 2003).

\section{Project completion}

In May 2004 a new design by artist and sculptor Kingsley Baird was selected as part of a publicly notified resource consent submitted by the $\mathrm{MCH}$. The new design was able to convey the necessary messages and meanings of the MCH's design brief while respecting the existing NWM site.

Built into the forecourt steps of the NWM, the classically shaped tomb featured distinctive New Zealand symbolism and iconography. Along the base of the TUW was etched a karanga (ceremonial call), in English and Māori, calling the Unknown Warrior back home to New Zealand. Takaka marble crosses were set into the black granite of the tomb to represent the Unknown Warrior's comrades who died in service and remain overseas. The bronze lid of the TUW features four inlaid Pounamu crosses, alluding to the Southern Cross constellation, which form part of the New Zealand flag (Ministry for Culture and Heritage 2005).

On 6 November 2004 the remains of an unidentified New Zealand soldier of the First World War were exhumed by Commonwealth War Graves Commission staff from the Caterpillar Valley Cemetery on the Somme in northern France. They were returned to the care of a New Zealand Defence Force contingent at a ceremony at the New Zealand Memorial at Longueval in France, and then flown back to Wellington on a Royal New Zealand Air Force 757 aeroplane. On 10 November 2004, the Unknown Warrior was welcomed at Parliament by the Governor-General and Prime Minister. He lay in state until a memorial service was held the following morning at the Wellington Cathedral of St Paul. The memorial service was followed by a military funeral procession through central Wellington to the NWM, where the 
Unknown Warrior was laid to rest in the newly created TUW. The return of the Unknown Warrior was enthusiastically embraced by the New Zealand public - an estimated 10,000 filed past his coffin as he lay in state at Parliament, while another 100,000 lined the streets of Wellington to watch the military procession to the NWM.

In conclusion we can see from the TUW project history that the construction of this memorial was a contested and negotiated process. The key messages for the $\mathrm{MCH}$ led project revolved predictably around issues of nationalism and national identity. The TUW was to be a symbol of unity for New Zealanders of all generations and a tangible site for the public to remember the nation's war dead. The vigorous opposition to the initial Tomb plan ensured that the final design was a far more inclusive process. Legal proceedings regarding the protection of the built heritage of the NWM saw MCH carry out a transparent design selection and undertake extensive consultation with heritage protection groups. Despite the controversy over the design of the Tomb the public responded enthusiastically to the repatriation of the Unknown Warrior and visited the NWM in larger numbers than previous years following his interment. The increase in visitor numbers throws up several interesting questions. What were the motivating factors for these visitors? How did they interpret this experience? The next chapter looks at the research methods I employed to capture this information and outlines the theoretical foundation from which I approached my visitor research. 


\section{Chapter 3: Methodology}

As mentioned in the previous chapter my dissertation explores how visitors to the TUW interpret and construct meaning from their visit. In order to access this information I carried out visitor research at the NWM in Wellington. This took place in two phases. In the first phase I looked at two samples of 500 visitor comments left in the NWM visitor books. Drawing on the information in the visitor comment books and the TUW project objectives I then compiled a nine-question survey, which was completed by twenty visitors during one-to-one interviews at the NWM.

In this chapter I outline the qualitative research methodology I used during my dissertation. I begin by summarising the constructivist, interpretivist, and phenomenological paradigms, which inform my research model, and examine their relevance to my research methods. I then move to examining my visitor book and survey research methods; highlighting the advantages of both methods and their application by researchers studying visitors at heritage sites. Following this, I outline the issues I faced analysing visitor book entries and administering my surveys. This section relates to site selection, research population, and the process of data gathering. I conclude this chapter by specifying the boundaries of my research at the NWM and outlining the procedures I followed to maintain ethical research practice.

\section{Methodological approach}

The visitor research methods above were part of a qualitative research model I adopted for this dissertation. Designed to allow interpretation and understanding of people's reasons for social action and the way they construct meaning, qualitative methodology is a diverse and pluralistic research model that contains elements from many schools of thought (Sarantakos 2004). My research model is underpinned by three theoretical paradigms - constructivism, interpretivism, and phenomenology. Constructivism focuses on the belief that the reality people experience in life is a constructed reality based on their interpretation of the world around them (Sarantakos 
2004). In other words, the meanings associated with physical objects such as the TUW are not fixed but emerge from visitors' reconstructed impressions of them.

The notion that meaning is constructed from cultural and historical interpretations and personal experience is explored further by interpretivist theory. The concept of interpretivism has its roots in the work of sociologist Max Weber (1864-1920). His theory of Verstehen (understanding) explored social life through the production of meaning and the views, opinions and perceptions experienced and expressed by people in everyday life (Sarantakos 2004). To illustrate his theory, Weber looked at interpretive research methods used by ethnographers to access subjective meaning from indigenous or sub-cultural groups (Sarantakos 2004). This dissertation draws on a similar research framework to explore the subjectivity of the visitor experience at the NWM, especially how visitors make sense of the TUW and assign meanings to it. People's perception of everyday social phenomenon is something that has been of particular interest to researchers working within the field of phenomenology.

Phenomenology is a philosophical method developed by Edmund Husserl (1859-1938) for the systematic reflection and analysis of phenomena. The basic aim of phenomenological research is to discover the structure of an event from the perspective of the individual experiencing it (Masberg and Silverman 1996). The subjective nature of the phenomenology methodology has seen it adopted by several researchers interested in the nature of visitors' experiences at heritage sites. Barbara Masberg and Lois Silverman (1996) used a phenomenological approach to explore the experiences of college students at heritage sites in the United States, while Konstantinos Andriotis (2009) employed a similar framework to look at the experiences of male visitors at the sacred site of Mount Athos (Holy Mountain) in Greece. Both studies employed similar visitor research methods as I used in my visitor research. Masberg and Silverman developed a visitor survey for use in their study. The survey consisted of five key open-ended questions designed to elicit respondents' perspectives on heritage sites they had visited. On the other hand, 
Andriotis studied the experience of visitors to Mount Athos by initiating conversations with visitors, engaging in participant observation, and reviewing narratives in visitor books kept in various monasteries.

While phenomenological studies have opened up new ground in this field, Masberg and Silverman (1996) argue that the majority of research into visitor experience at heritage sites still does not adequately explore the subjective perspective of visitors. In order to better understand how visitors make sense of their experience it is not enough to simply observe what they do or record demographic information. Purely quantitative methods do not often provide an understanding of the value of that experience to visitors, and are of limited use in developing knowledge of attitudes, values and feelings (Hooper-Greenhill 2006). Eilean HooperGreenhill (2006) believes a more interpretive and qualitative-based approach is required. The following section looks at the qualitative research methods I employed to try and elicit and present the discussions and meanings of visitors to the TUW.

\section{Research methods}

The two methods of inquiry I used during my visitor research for this dissertation were visitor books and visitor surveys. The NWM visitor books were a novel source of information and provided me with an insight into visitors' personal meanings of their memorial experience. As a research tool visitor comment books have their advantages. Since the comments are not written at the researcher's request, they minimize reactivity and maximise naturalness. In this way visitor books can be considered self-revealing and honest research instruments. Researchers are beginning to see visitor books as legitimate sources of lived experiences in which they can find practical insights. Sharon Macdonald (2005) has explored the use of visitor books as a source of information on visitors' views, experiences and understandings of the former National Socialist (Nazi) rally grounds in Nuremberg, while Konstantinos Andriotis (2009) used visitor comments left behind by male pilgrims to Mount Athos in Greece to help identify themes of visitor experience at this sacred site. 
Whether visitor books are more authentic than other sources is open to debate. Although visitor book entries tend to be formulaic the types of comments left are likely to vary among particular visitors and national and cultural contexts. For example, I found that the frequency of visitor comments left at the NWM increased on major commemorative occasions such as Anzac Day and Armistice Day. Whether this was due to an increase in visitor numbers or because people felt more inclined to leave a comment on these national days of remembrance is a subject for another piece of research. For Sharon Macdonald (2005) the key is to distinguish the different 'voices' within visitor books and understand the context of the inscription, although this can be difficult when there is almost no information left behind about those people leaving the comments.

The second visitor research method I used was a survey, which was completed by twenty visitors to the NWM. I chose to use the questionnaire format so that I could compare the responses of interviewees with the comments left behind in the NWM visitor books. As well as looking for ideas and themes present in both formats I also considered differences and disjunctions and possible reasons for these. For example, I was aware that survey respondents may be more forthcoming in a private face-to-face interview compared to entries left in a public visitor book. In reality, the tone of visitor responses in the visitor books and the surveys were fairly similar, although a small number of visitor book inscribers made explicit criticisms of the management of the NWM.

Surveys have been a traditional method of obtaining information on visitor experience at museums, art galleries and heritage sites. These institutional surveys have often used numerical scales and statistical models to assess the opinions of visitors. While quantitative survey templates enable the collection of valuable information regarding visitor numbers and the demographic profile of visitors, they offer little insight into the subjective nature of people's experience. In order to produce results that are closer to, and more accurate in relation to visitors' own 
meanings, survey design must also incorporate interpretive questions. Benjamin Forest and Juliet Johnson (2002) adopted this approach when they looked at the integration of Soviet-era monuments into post-Soviet national identity. In an effort to assess the reception of places of memory in Moscow, Forest and Johnson administered a survey to a sample of 501 Russians visiting four different monument sites. The survey contained basic demographic questions and several structured questions to assess the frequency and purpose of the respondent's visit, and questions to measure political party and religious affiliation. In addition, respondents were asked to answer six open-ended questions regarding contemporary political and social developments, so that the researchers could assess political attitudes and nationalistic sentiments (Forest and Johnson 2002). In the following section I look at the practical aspects of my visitor research methods and examine issues of site selection, research population, and data gathering.

\section{Site selection and research population}

The NWM in Wellington was an obvious place to conduct my visitor research as it provided me with the opportunity to administer a survey on the same site as the TUW. I was familiar with the site, having undertaken a visitor research project there on behalf of $\mathrm{MCH}$ in November 2008. This project gave me practical experience of conducting research at the NWM, especially in terms of where I positioned myself within the NWM. For example, I discovered that the best place to approach visitors was near the main doors to the Carillon tower. As well as being the main entry and exit point for visitors entering the NWM it allowed me to observe the movements of visitors inside the Hall of Memories and outside near the TUW.

In terms of my research population I was primarily interested in New Zealand visitors to the NWM who were 16 years and over. These included visitors from within Wellington city, the greater Wellington region and the rest of New Zealand. While my survey respondents fell within these parameters, both samples of visitor 
comments I analysed included entries made by international visitors and visitors under the age of 16 .

\section{Data gathering}

In terms of data gathering I collated two samples of 500 visitor comments from the NWM visitor books. The samples included all visitor comments listed in the visitor books during two periods: 11 November 2004 - 16 January 2005 and 11 November 2007 - 18 June 2008 . I chose to analyse two time periods beginning Armistice Day (11 November) in order to compare visitor comments left immediately following the interment of the Unknown Warrior with those made three years after the event. The difference in the duration of each sample period is due to the higher concentration of visitor comments left during the surge in visitor numbers at the NWM following the interment of the Unknown Warrior. ${ }^{7}$

Once I completed my analysis of the visitor comment samples I constructed a short survey designed to investigate the aims and objectives of the TUW project (see Appendix 1). This survey incorporated both quantitative and qualitative questions. The quantitative questions related to visitor demographics and visitation history, while the four main questions were designed to elicit qualitative information on visitors' perceptions of the significance of the TUW at both a national and personal level. The strength of this approach is that it gives the respondent the freedom to express feelings and thoughts, especially when complex issues are being studied. Sotirios Sarantakos (2004) argues that open-ended questions capture more details than pre-coded questions, especially qualifications and justifications, and allows the researcher to draw conclusions about the respondents' way of thinking and logic.

\footnotetext{
${ }^{7}$ The Ministry for Culture and Heritage Annual Report 2005 noted that some 40,000 people visited the NWM and the TUW in the year after the interment of the Unknown Warrior, up from an annual total of 2,500 visitors previously. This figure was based on weekly visitor number charts completed by NWM curatorial staff during this period.
} 
I decided not to pilot study my survey on the basis that I had used a similar survey format during a previous visitor research project at the NWM in November 2008. This template had been able to generate sufficient information on visitor demographics, visitor history and visitor experience, and the survey experience had given me an insight into the practicalities of accessing visitors at the NWM. For this dissertation, I conducted surveys with twenty NWM visitors over a three-month period, 29 April - 29 July 2009. My sample number was limited by several factors. Time and work commitments meant I was only able to be present at the NWM two days each week. In addition, my research period fell outside of peak visitor season at the NWM, while external factors such as poor weather and competing entertainment events in Wellington also influenced visitor numbers.

Visitors were requested to complete a survey as they left the NWM. My surveys were conducted in two hour periods at different times on both weekdays and weekends during a three-month period (see Appendix 2). I tried to ensure representative sampling by using a quasi-random sampling method known as systematic or interval sampling (Schutt 2006). Interval sampling employs a gap, or interval, between each selected unit in the sample. During each session of visitor research at the NWM I employed a sample interval of one visitor per thirty minutes. In other words, I waited thirty minutes from the beginning of each visitor interview before I attempted to survey my next visitor. I employed this interval sampling for each two-hour period of visitor research I conducted at the NWM (see Appendix 2).

Rather than use a mail-out or self-complete survey I decided to administer the surveys face-to-face with visitors. There were several distinct advantages to this method. Non-response was zero and it was easier to establish a rapport with the respondents. Face-to-face contact also allowed me to employ prompting techniques when I needed clarification on an answer or the respondent appeared hesitant or confused. Finally, I had more logistical control over the research process - I did not have to wait for surveys to be returned, which allowed me to be more flexible with my research schedule. 


\section{Data analysis}

In an attempt to identify themes within the visitor comments I searched for commonalities and differences in content. I did this by employing a constant comparative method of data analysis developed by sociologists Barney Glaser and Anselm Strauss (1967). The constant comparative method analyses qualitative data in four distinct stages. First, the key points from the data are marked with a series of codes or units of meaning. The codes are then grouped into similar concepts in order to make them more workable. From these concepts, categories are formed, from which the researcher can develop theoretical findings (Sarantakos 2004). I used a similar process to analyse my two samples of visitor comments. This involved grouping comments under an initial set of broad headings, which were reworked and revised until I felt that the full range of visitor responses had been categorised. Once all the comments had been grouped I was able to incorporate a degree of quantitative analysis into my research and gauge which kind of comments were more frequent than others.

When it came to analysing the survey responses I employed the same constant comparative method as I did with the visitor book samples. To begin with I entered all the visitor responses to each question into a spreadsheet. By reading and rereading this information I was able to identify recurring concepts, phrases, topics, patterns and themes, which I colour-coded into different categories of meaning. These categories were compared with others and re-grouped into similar units of meaning. I continued with this process of refinement until all the survey responses had been categorised. The next section identifies some of the limitations of my research.

\section{Research limitations}

Several limitations of this study must be noted. The first is in relation to the nature of the information obtainable from visitor book entries. First, the majority of the visitor comments I looked at were very succinct, and only revealed a small aspect 
of the visitor's experience. The anonymity of some entries and the absence of sociodemographic characteristics were also problematic in terms of establishing a profile of NWM visitors. This in turn, made it difficult to establish whether the visitors who left these comments were a representative sample of all NWM visitors. According to Konstantinos Andriotis (2009) information gained from visitor books cannot be claimed as representative for all visitors to a heritage site since most people find writing difficult and tend to talk more eloquently and with less reserve than when writing on paper. Despite these limitations, I found the use of visitor books, especially in conjunction with the surveys, provided a deeper understanding of visitors' experiences.

My survey sample was comprised solely of visitors of New Zealand/European or Pākehā descent. This was not a conscious decision on my part but a reality of the characteristics of the New Zealand visitors I encountered during my periods of visitor research.

The size of my research sample was determined by the conclusion that once I had surveyed twenty visitors, theoretical saturation had been achieved. Theoretical saturation is the point at which additional interviews add no new ideas or themes to a research project (Wengraf 2001). Although my research sample was small despite the long research period this is mitigated by the fact that after twenty visitor survey interviews I felt I had reached theoretical saturation - respondents were providing similar responses to each question and additional surveys were unlikely to throw up any new information.

\section{Ethical research practice}

I attempted to follow a strict standard of ethical research practice during my visitor research at the NWM. One of the most important ethical issues I had to consider was the issue of reflexivity. Reflexivity is the ability of researchers to be aware that they are also participants of the social world they are exploring, and that 
their research does not simply produce descriptions of reality but also constructs it as well (Elliot 2005). This was an important consideration when it came to analysing my research and the role I played in the research process.

Using NWM visitor entries as a research source did not present a major ethical dilemma since these comments had been left voluntarily and were open to the public gaze. In fact, the tone of several entries suggested that, for a number of visitors, the motivation for leaving comments was that other visitors would read them.

They've sold our war memorial to a university that isn't even based here. What a way to treat those who've made the supreme sacrifice (Male, NZ).

Nevertheless, I maintained the anonymity of those visitors whose comments I quoted by only reproducing gender and nationality details.

When it came to administering my surveys I adhered to a code of ethics established by Victoria University of Wellington for research involving written questionnaires (Human Ethics Committee 2003). This human ethics policy covers issues of anonymity, sensitive content, and disclosure. In terms of my survey, I ensured the anonymity of respondents by only recording details on their age, gender, and place of origin. In addition, I tried to make the research process as transparent as possible. Included with each survey was an information sheet (see Appendix 3), which provided respondents with information on how the results would be used, the disposal of the survey forms, and the anonymity of their participation.

My methodology is based on qualitative research paradigms that focus on the subjectivity of social life and the various ways people construct and interpret particular meanings from events and other social phenomenon. This methodology has been adopted by several researchers looking at the experiences of visitors at various sites of significance (Andriotis 2009; Masberg and Silverman 1996; Macdonald 2005; Forest and Johnson 2002). These studies used methods such as open-ended surveys 
and visitor book analysis to move beyond purely observational and demographic research to explore attitudes, values and feelings. This dissertation employed the same research methods to study visitors to the TUW. The NWM visitor books gave me to access to visitor perspectives that were not premeditated or influenced by my research questions, while the open-ended nature of my survey questions enabled me to examine in detail the messages and themes that emerged from visitor books. In the following chapter I analyse the material I collected through these methods and discuss the findings. 


\section{Chapter 4: Analysis and discussion}

In this chapter I analyse the findings of the visitor research I conducted at the NWM and discuss some of the significant trends and themes that have emerged. I begin by looking at the NWM visitor book entries. I outline the gender and nationality characteristics of visitors in each sample, as well as some of the different types of visitors making entries. Next I explain the process of grounded thematic coding I used to categorise the visitor comments. I then move onto consider these themes by analysing and discussing related entries drawn from the NWM visitor books and the material I collected from my visitor survey respondents.

\section{Visitor comment books}

I looked at two samples of 500 comments left in the visitor books at the NWM. The samples were taken from two different periods. The first set of comments was from a two-month period between November 2004 and January 2005, which included the interment ceremony for the TUW on 11 November 2004. The second set of comments was taken from a seven-month period almost three years laterNovember 2007 to June 2008. I chose these periods to ensure I covered visitor comments left following the Unknown Warrior's interment and those made once the TUW had become an established feature of the NWM.

The duration of each sample period was determined by how long it took to accumulate 500 comments. This was done using the date inscriptions in the visitor books. The time difference between the first and last entry in each sample; two months for the sample one versus seven months for sample two, reflects the high concentration of comments left in the NWM visitor books following the interment of the Unknown Warrior. According to the MCH's 2005 Annual Report, some 40,000 people visited the NWM in the six months following the interment ceremony (Ministry for Culture and Heritage 2005). 


\section{Visitor types}

The majority of visitor comments in each sample were accompanied by the visitor's name, date of visit, gender, and place of residence. This brief set of biographical information provided some clues as to the socio-demographic make-up of the visitors in these samples. Place of residence was usually given as a city or region, or country, especially when the visitor was from outside New Zealand. From this information I calculated the gender and national/international origin figures for each sample (see Figures 1.0 and 1.1).

\section{FIG. 1.0 - GENDER OF VISITORS IN SAMPLES 1 \& 2}

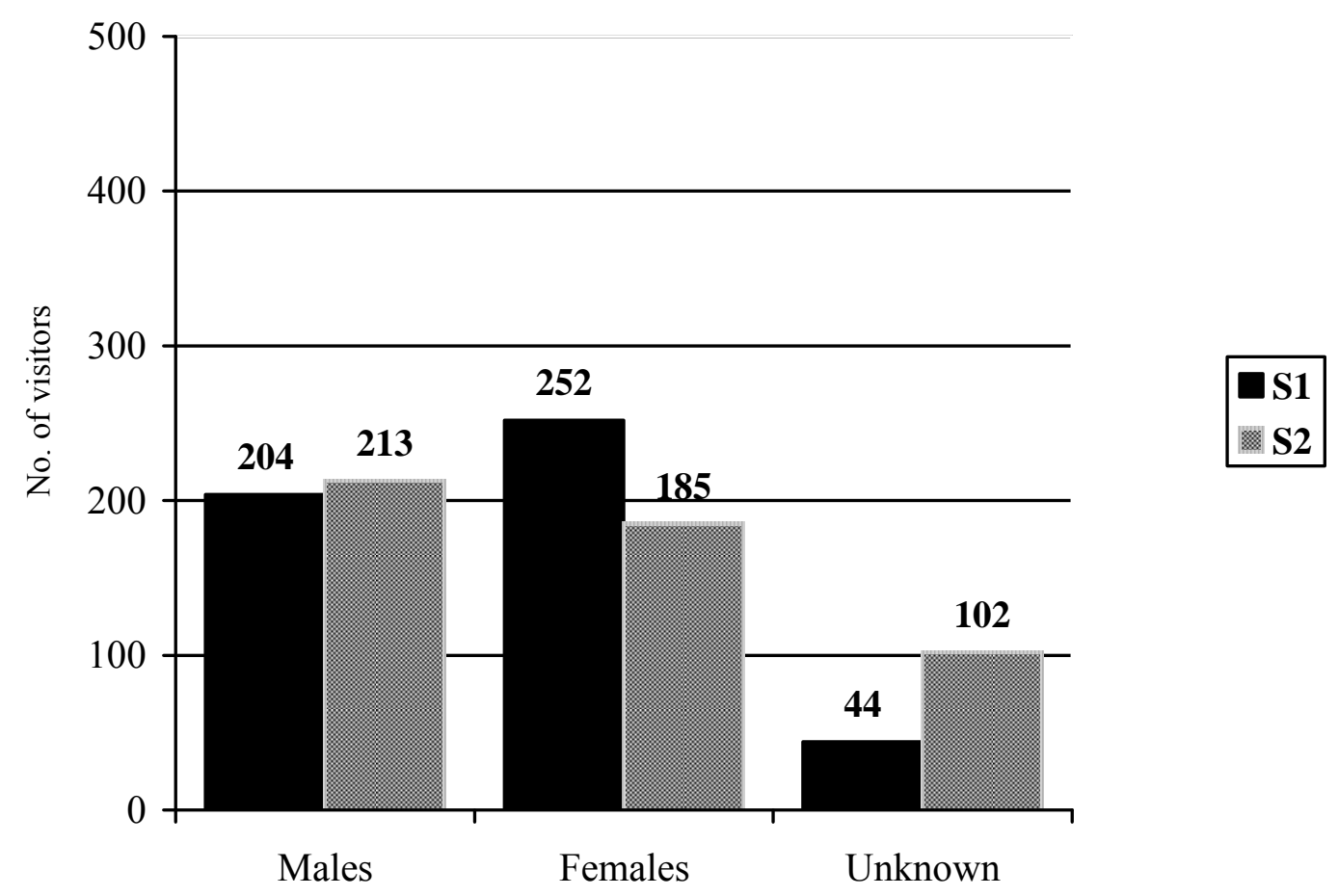

The gender makeup of visitors who left entries in Sample 1 (S1) was 40.8\% males and $50.4 \%$ females. The gender of the remaining $8.8 \%$ of visitors could not be 
ascertained due to a lack of identifiable information. In Sample 2 (S2) the gender breakdown was $42.6 \%$ males; 37\% females; and 20.4\% unknown gender.

\section{FIG. 1.1 - NATIONALITY OF VISITORS IN SAMPLES 1 \& 2}

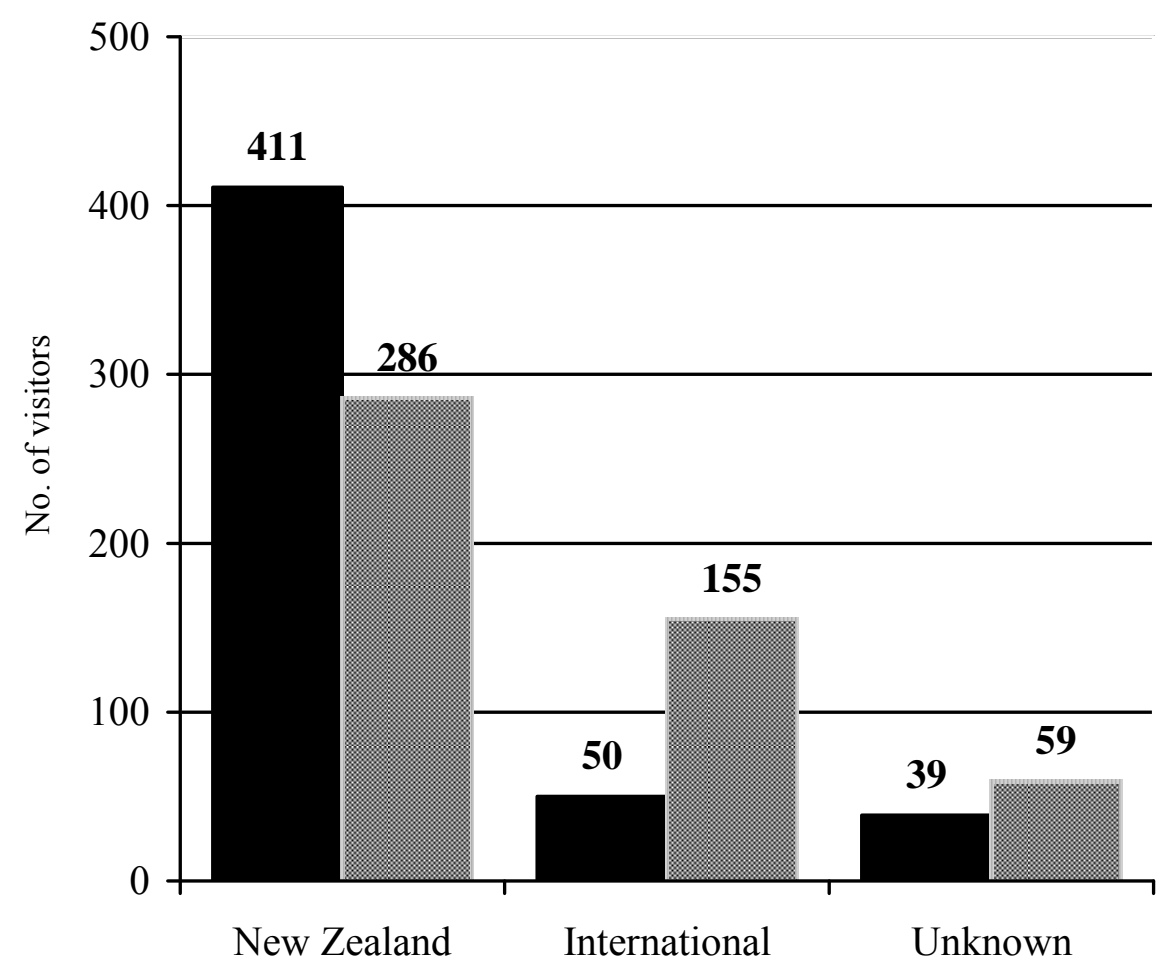

The majority of visitors who left entries in the two samples of comments I examined were from New Zealand. In S1 82.2\% visitors listed their country of origin as New Zealand, while $10 \%$ were from overseas. The remaining $7.8 \%$ did not list their country of origin. In S2 $57.2 \%$ of visitors identified New Zealand as their country of origin; 33\% were from overseas; and 9.8\% were of unknown nationality. Of those international visitors identified in both samples the majority were from the United Kingdom, Australia and the United States (see Figure 1.2). 


\section{FIG. 1.2 - NATIONALITY OF INTERNATIONAL VISITORS IN}

SAMPLES $1 \& 2$

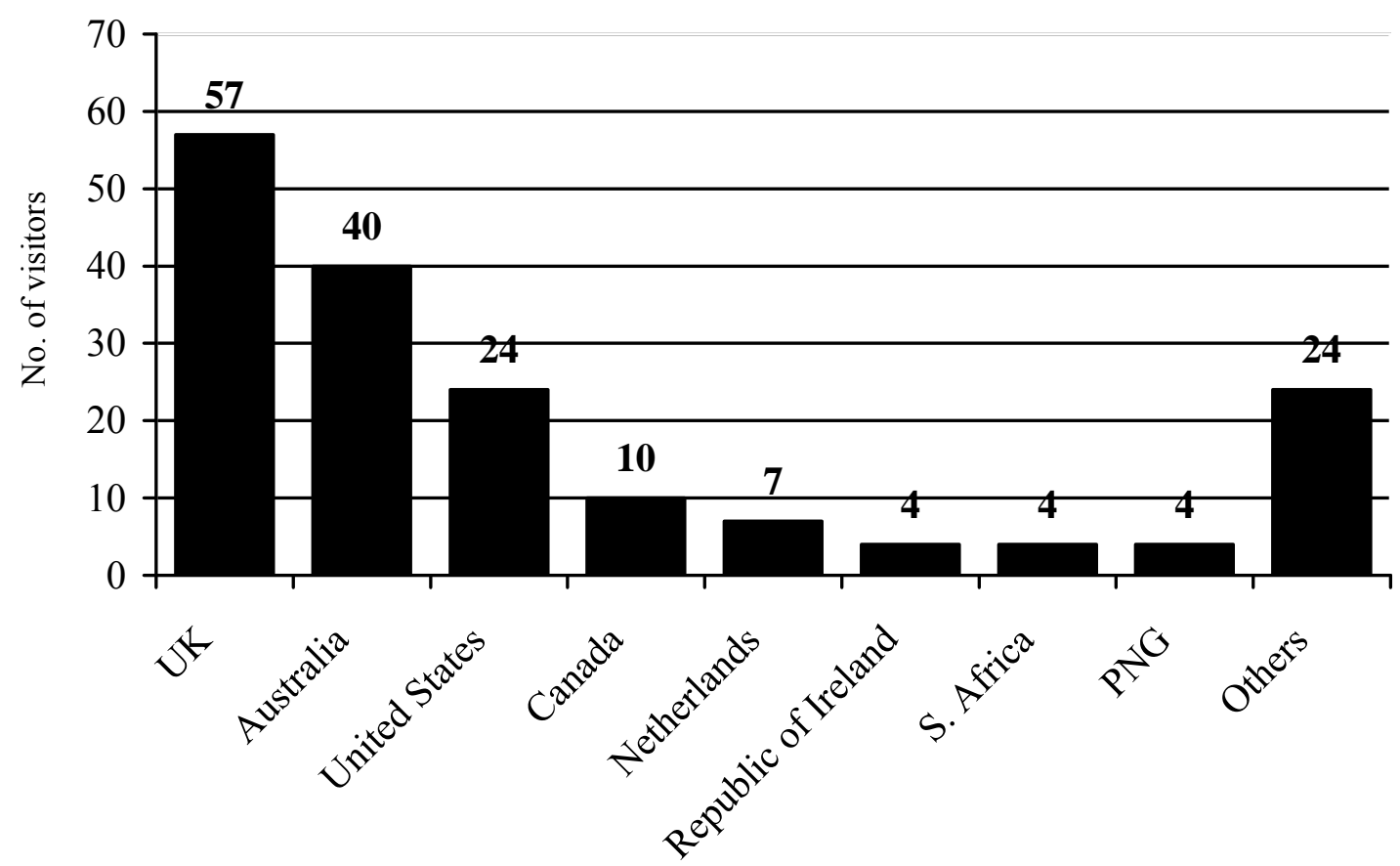

The total number of international visitors who left comments in S1 and S2 was 174 . Of these $32.8 \%$ were from the United Kingdom; ${ }^{8} 23 \%$ from Australia; 13.8\% from the United States; 5.7\% from Canada; 4\% from the Netherlands and $2.3 \%$ each from the Republic of Ireland, South Africa and Papua New Guinea. The remaining 13.8\% were made up visitors from China, Thailand, Uruguay, France, India, Pakistan, Czech Republic, Fiji, Germany, Malaysia, Italy, Indonesia, Tonga, Japan, Norway, and Finland.

Aside from gender and nationality the language used by visitors in making their comments also provided clues to the different visitor groups visiting the NWM. Younger visitors were fairly distinguishable. Visiting school groups were usually

\footnotetext{
${ }^{8}$ The United Kingdom includes visitors from England, Wales, Scotland, and Northern Ireland.
} 
noted as such and graffiti-style writing and language were good indicators of a visitor's age.

Just an awesome place! Nayland College Yr 12 History (Female, $\mathrm{NZ}$ )

Y-T-T WAT! Mu an' Korou waz here (Male, NZ)

A small number of comments in each sample were written in Māori - 7/500 in $\mathrm{S} 1$ and 2/500 in S2. The majority of these entries were left in regards to the Unknown Warrior and acknowledged his commitment in battle, his family and ancestors, and the return of his spirit. ${ }^{9}$ The presence of these entries suggests that Māori are another visitor group to the NWM.

Hoki wairua mai (Male, NZ)

Au te marae - mei te aroha (Female, NZ)

Perhaps the most identifiable visitor group in both samples of visitor comments were war veterans and military personnel. While it was relatively unusual for visitors to present anything more than cursory personal notes, this group often made deliberate links to their personal biographies, especially the details of their military service and the various veteran organisations they belonged to.

$864^{\text {th }}$ Engineer Battalion, US Army Vietnam '68. We thank you for the sacrifices you made from all the vets in Chicago (Male, US)

Royal British Legion, Hampton Branch. Forever grateful (Male, $\mathrm{UK})$

\footnotetext{
${ }^{9}$ I had all visitor entries written in Māori translated into English by a colleague fluent in Te Reo Māori.
} 


\section{Visitor book analysis}

My strategy for analysing the visitor book entries was to use a system of thematic coding. The process of thematic coding involves the generation of 'codes' or themes from raw information. For researchers, coding helps link this raw information with thematic ideas that reveal their respondents' understanding of the social world (Gibbs 2007). When it came to analysing the NWM visitor comments I employed a method of open-coding favoured by advocates of grounded theory (Glaser and Strauss 1967) and phenomenological research (Masberg and Silverman 1996). In this approach the researcher does not apply predetermined codes to their research but teases them out as they read through the information.

I began by reading through the two samples and making notes on types of entries that seemed to reoccur. From this I generated a set of headings related to themes and topics that visitors seemed to be addressing directly and implicitly. Working my way through the sample I added, deleted or modified headings until I settled on the nine 'codes' relating to place; remembrance; the Unknown Warrior; thanks and gratitude; personal connection; condolence; peace; nationalism; and the inability or refusal to comment. Visitor entries were entered under each theme into a spreadsheet using date, name, nationality, and comment details. This process was repeated until all the comments in my samples had been coded within a theme (see Figure 1.3).

The following table presents this information in quantifiable form. It must be noted that there are more than 500 comments noted in each sample - 534 in S1 and 510 in S2. This is because there were instances of entries covering several themes. The main areas of overlap seem to be entries relating to remembrance and the Unknown Warrior. For example, some entries that referred to the act of remembering also touch on aspects of nationalism, place, and the Unknown Warrior.

I came to commemorate those who fought and died for NZ (Male, NZ) 
Never to be forgotten. A perfect memorial (Female, NZ)

Your return has moved us and reminds us to remember and value our lives (Female, NZ)

In addition, there were entries left about the Unknown Warrior, which expressed nationalism, condolence and sympathy, and a debt of thanks.

NZ deserves to have him back. Well done (Female, NZ)

Welcome home, RIP and thank you for my family and your life (Female, NZ)

May you rest in peace at home (Male, NZ)

\section{FIG. 1.3 - THEMES OF COMMENTS IN SAMPLES 1 \& 2}

\begin{tabular}{|c|c|c|}
\hline \multirow[t]{2}{*}{ Themes } & \multicolumn{2}{|c|}{ No. of comments } \\
\hline & Sample 1 & Sample 2 \\
\hline Place & 169 & 185 \\
\hline Remembrance & 103 & 71 \\
\hline The Unknown Warrior & 58 & 6 \\
\hline Gratitude & 51 & 60 \\
\hline Personal connection & 50 & 62 \\
\hline Condolence & 48 & 8 \\
\hline Peace & 29 & 29 \\
\hline Nationalism & 19 & 11 \\
\hline No comment & 7 & 78 \\
\hline Total & 534 & 510 \\
\hline
\end{tabular}

In the following section I examine the main characteristics of each of the visitor comment themes. 


\section{Themes}

\section{$\underline{\text { Place }}$}

The most prevalent type of comment in both samples was related to tangible and intangible aspects of the NWM and its surrounds $-31.4 \%$ in S1 and 36.3\% in S2. These particular comments included general references to physical aspects of the NWM including its architecture, landscaping and maintenance.

Beautiful space and design (Male, NZ)

This structure is an architectural gem (Male, England)

Specific references were made to design aspects of the Carillon tower and the adjoining Hall of Memories.

Beautiful memorial. We'll come back to hear the bells (Female, $\mathrm{NZ}$ )

Amazing tribute. I like the stained glass windows. Wow! (Female, NZ)

As well as the physical elements of the memorial, visitors also commented on the emotional impact that the NWM had on them. Some entries described the NWM as powerful, moving and peaceful, while others emphasised the spirituality of the visitor experience and expressed sadness at the thousands of lives that were being memorialised.

A place of deep abiding peace (Male, NZ)

It makes my heart ache (Female, NZ)

Other entries I grouped under this heading were those comments that referred to specific details of the inscriber's visit or previous visits made to the NWM. These 
included references to NWM staff, visitation history and access to restricted areas of the memorial.

A privileged visit for a musician. Thank you Tim (Male, England)

50 years of visiting this special place (Female, NZ)

Is it possible to be shown the upstairs area of this building?

(Unknown)

\section{$\underline{\text { Remembrance }}$}

The second largest group of comments were those related to remembrance $19.3 \%$ in S1 and $13.9 \%$ in S2. Visitor entries emphasised the need to remember the sacrifices New Zealanders have made in past wars.

We will never forget the ones who gave their lives to protect others (Male, US)

Never forget the hardship so we may continue with the present (Female, NZ)

For some visitors the NWM was an important educational tool in increasing awareness, especially amongst younger generations, of the sacrifices of past generations.

Wonderful monuments like this mean the youth of today won't forget (Unknown)

An important experience for our children (Male, NZ)

The majority of entries linked to the theme of remembrance employed traditional commemorative language such as 'We remember them' and 'Lest we forget' - phrases taken from the Ode of Remembrance read during memorial services on commemorative occasions such as Anzac Day. Although the majority of these 
entries positioned the inscriber as part of a collective group of rememberer(s), there were others who made a more personal statement.

I salute all the Fallen, always remembered never forgotten (Male, NZ)

I came to commemorate those who fought and died for NZ (Male, $\mathrm{NZ}$ )

\section{The Unknown Warrior}

Only a small number of visitor entries made a direct reference to the Unknown Warrior $-10.9 \%$ in S1 and $1.2 \%$ in S2. The majority of these comments were messages of welcome and emphasised the fact that the Unknown Warrior was home after a long time away. In a few cases, references were made to symbols of New Zealand national identity to reinforce this point.

Welcome home to the long lost son (Female, England)

At last he is home (Male, NZ)

So happy to know you can hear the Tui's sing again (Female, NZ)

Although the bulk of visitor entries concerning the Unknown Warrior were positive, a small number of comments raised issues concerning his anonymity and the terminology used in his title.

Who are $u$ ? (Female, NZ)

Sad you couldn’t identify him (Female, NZ)

'Soldier' not Warrior! (Female, NZ) 


\section{Gratitude}

Another set of entries expressed gratitude to those New Zealanders who served their country and lost their lives during times of war $-9.6 \%$ in $\mathrm{S} 1$ and $11.2 \%$ in $\mathrm{S} 2$. Although the majority of comments focused on the Unknown Warrior and New Zealand war dead in general, several also acknowledged the service of veterans from specific wars.

Thank you brave soldiers (Female, NZ)

To lives lost - thank you for your support (Male, England)

For all the men who went, sometimes against their will, to fight and be injured or die in the bloody jungles of Vietnam, we owe them honour no less than those who fought in any war (Male, NZ)

In addition to acknowledging war dead and veteran groups there were also similar entries addressed directly to the 'makers' or curators of the TUW and NWM.

Thank you for this peaceful place (Female, NZ)

Love your work with the poems (Male, NZ)

Thank you for the tour and all your time (Male, NZ)

\section{Personal connection}

A third category of visitor comments highlighted personal and familial connections with war dead $-9.7 \%$ in S1 and $12.2 \%$ in S2. The majority of visitors who left these types of entries were New Zealanders - 91.3\% in S1 and 82.3\% in S2. This type of entry commemorated the service of military ancestors and acknowledged their possible connection to the Unknown Warrior. The majority of the comments were intergenerational messages - 'goodbye Dad', 'love you poppa' - from children and grandchildren in memory of family who had served in past wars. 
As a grandson of two warriors from Chunuk Bair I am humbled, thank you New Zealand (Male, NZ)

Sixty-three years ago today my father was shot down and killed in Germany. He was a pilot in 486 Squadron flying a Tempest (Female, NZ)

Within this category of visitor comment, a small number of entries $-6 \%$ in $\mathrm{S} 1$ and $4.8 \%$ made personal connections to the Unknown Warrior and the wider NWM.

Glad you're back in New Zealand Sid (Female, NZ)

The stone for this memorial came from grandparents quarry, Putaruru Building Stone (Male, NZ)

\section{$\underline{\text { Condolence }}$}

Visitor entries also employed traditional western funerary language to express their condolence and sympathy for the war dead commemorated at the NWM $-9 \%$ in $\mathrm{S} 1$ and $1.6 \%$ in S2. Expressions such as 'rest in peace' were prevalent in comments left in the immediate period following the interment of the Unknown Warrior. This may have been because the funerary aspects of this ceremony prompted visitors to use this terminology.

Kia kaha brave warrior. Rest in peace (Male, NZ)

Rest in peace. Sleep well and enjoy your new home (Female, NZ)

\section{$\underline{\text { Peace }}$}

Another set of visitor comments was associated to the idea of peace $-5.4 \%$ in $\mathrm{S} 1$ and $5.7 \%$ in S2. These entries focused on the human cost of war and expressed the hope that the sacrifices of New Zealand's war dead would not be in vain.

May it never happen again (Female, NZ)

Doesn't war suck? So many wasted lives (Male, NZ) 


\section{$\underline{\text { Nationalism }}$}

There were very few overtly nationalistic comments $-3.6 \%$ in S1 and $2.2 \%$ in S2.

I feel proud to be a Kiwi. God bless all the soldiers willing to sacrifice their lives for NZ (Female, NZ)

Proud to be a Kiwi (Female, NZ)

\section{Non-specific comments}

The final group of visitor entries were those that made non-specific references or no comments at all $-1.3 \%$ in $\mathrm{S} 1$ and $15.3 \%$ in $\mathrm{S} 2$. This selection included visitors who indicated why they did not say anything specific about their visit, as well as those who declined or were unable to elaborate on their experience for whatever reason.

No words come to mind (Male, NZ)

What can we say? (Female, NZ)

Several linkages can be made between the themes above. The first is the relationship between the themes of remembrance and place. Visitors commented on aspects of the memorial's design and atmosphere in regards to their remembering. This attitude was reflected in several entries. On another level, several entries acknowledged the importance of the memorial to the act of remembering. Several suggested that the memorial should be a form of universal civic education. Related to this is the idea that the TUW should constitute a reminder of the cost of war and an exhortation to remember so that we never go to war again.

Quiet and serene surroundings to reflect on our fallen (Female, NZ)

This should be required visiting to all who come to Wellington (Male, USA) 
Never forget the hardship so we can continue with the present (Male, NZ)

Another link can be established between remembrance and personal connection. Personal connections encouraged visitors to commemorate friends and family members who had served and/or died during wartime. These entries were intergenerational and located the act of remembrance within a personal narrative.

My mother mourned every day for her brother who survived Gallipoli and was killed in France, 1917 (Female, NZ)

Finally, connections are also evident between expressions of gratitude, remembrance and aspects of nationalism. In communicating their gratitude to New Zealand's war dead, visitors positioned their remembering within a collective national narrative. In addition, the visitor comment books at the NWM provided a platform for them to lobby other New Zealanders to do the same.

They gave their today for our tomorrow (Male, England)

Every New Zealander should visit (Male, NZ)

In the next section I discuss the results of my visitor comment book analysis. I begin by considering trends revealed in the gender and nationality composition of the visitors in my samples. I then move onto discussing further some of the relationships between the themes above and conclude by looking at the Unknown Warrior in relation to the comments left by visitors.

\section{Discussion: Visitor book comments}

The visitor book comments I looked at provided a subjective and selfreflexive picture of visitor interpretation at the NWM over a three year period. In analysing the different themes of comments (see Figure 1.3) the majority of these entries were in some way connected with ideas of place, family and ritual. In terms of place, visitors consistently made connections to the emotional aspect of their 
experience and the impact of the memorial environment on their remembrance. The TUW and the surrounding NWM were described as 'peaceful' and 'spiritual'; a place that enabled visitors to 'reflect', express their 'thanks' or 'heartache'. For these visitors the memorial is 'charged with meaning' - an expression used by Bruce Scates (2006) to describe the landscape encountered by visitors to the battlefield cemeteries at Gallipoli. Like Scates' pilgrims the views of visitors to the NWM were formed in relation to their own personal experiences. While I acknowledge that many of the entries are too succinct to surmise on the reasons for visitors' comments there are glimpses. For example, an Australian veteran recalled serving alongside his 'Anzac brothers' in Vietnam; while a son remembered the grief of his mother who 'mourned everyday for her brother who survived Gallipoli and was killed in France, $1917^{\prime}$.

The importance of family connections is evident throughout both samples of visitor comments. Sons, daughters, nephews and nieces remember fathers and uncles who left for war but did not come back, while grandchildren and great-grandchildren acknowledge the service of soldier ancestors they have never met. The interest in family history has emerged as part of the 'rediscovery' of New Zealand's war memory and commemoration (Clarke 2008). Present-day New Zealand remains fascinated with elements of our war history because they represent events we cannot remember yet form the basis of the mythology of our national identity. The presence of soldier ancestors helps connect visitors to the NWM to these national narratives and forms them into what Benedict Anderson (1991) has labelled 'imagined communities'. This does not mean that visitors to the NWM can be defined as a homogeneous group. While entries show that many visitors shared a sense of debt to those 'saviours' and 'protectors' that fought and died for 'our generation'; others commented on the waste and futility of war. The death of the Unknown Warrior and nearly 30,000 other New Zealanders was keenly felt by those visitors who emphasised the importance of maintaining peace and using memorials such as the TUW as warnings against participating in future wars. 
In terms of visitor entries dedicated to the Unknown Warrior several themes emerged. Aside from direct references there are also entries related to themes of gratitude and personal remembrance. For instance, there are various comments, which thank the Unknown Warrior for his service and acknowledge the impact it has had on subsequent generations. Other visitor entries associate the Unknown Warrior with the service and sacrifice of military ancestors.

Thank you, without you we wouldn't be here today (Female, NZ)

Thank you for fighting for our generation (Male, NZ)

I feel my brother is represented here (Female, NZ)

The next main difference between samples is the prominence of entries related to condolence in $\mathrm{S} 1$. These comments are predominantly associated with the Unknown Warrior and express the hope that he 'rest in peace' at the NWM. Entries of this nature are characterised by the use of language from Western funeral rituals.

Rest in eternal peace (Female, NZ)

May you rest in heaven as you served your time down here (Female, NZ)

The prevalence of entries related to the Unknown Warrior and the use of funeral condolences in $\mathrm{S} 1$ is perhaps not surprising given the social and historical context of this sample period. Visitor entries in S1 were made at the same time as the Unknown Warrior's return to New Zealand and his interment at the NWM. This was a period of intense ritual and ceremony. The Unknown Warrior was effectively granted a state funeral on his return to New Zealand. After lying in state at Parliament, a memorial service was held at the Wellington Cathedral of St Paul, followed by a military funeral procession to the NWM where he was interred in the TUW with full military honours. These ceremonies evoked a level of emotion amongst the New Zealand public. An estimated 10,000 people paid their respects as 
the Unknown Warrior lay in state at Parliament, while another 100,000 lined the streets of the central Wellington to watch the military procession to the NWM.

This mix of highly publicised ceremonial ritual and interment of human remains seemed to resonate with New Zealand visitors to the NWM during this period. The entries devoted to the Unknown Warrior and the use of ritualised funeral language seem to reflect this. In a newspaper article published just after the establishment of the TUW, author Jim Traue (2005) wrote that New Zealanders, especially Pākehā New Zealanders, had embraced the return of the Unknown Warrior because it was civic ritual with deep roots in European heritage. The interment of the Unknown Warrior was essentially a civic ritual bound to the concept of citizenship. In early Greek and Roman states every citizen was obligated to fight and if necessary die in return for the privileges of citizenship. Death and burial were rites of passage indelibly linked to civic responsibility, and through the military, to the power of the state. This idea was widely adopted after the formation of citizen armies in the nineteenth century.

Pākehā New Zealanders have traditionally been uncomfortable with civic rituals. According to Traue, New Zealand has not been able compete with the grand spectacles of national identity of the United States, Europe and latterly, Australia (Traue 2005). This situation has been compounded by continued debates over the nature of Pākehā identity in a bi-cultural nation. Indeed, it has been argued Pākehā have found it easier to adopt aspects of Māori symbolism and ritual (Buchanan 2007). However, the groundswell of support given to the Unknown Warrior project and types of entries left in the visitor books suggests that Pākehā New Zealanders are becoming more receptive to ritual observances as a means of expressing community, establishing continuity with past, and provided a framework of meaning (Traue 2005).

The gravitas and the emotion surrounding the rituals experienced in November 2004 also seemed to encourage people to provide some form of comment. In S1 only 
$1.3 \%$ of visitors who wrote in the visitor book did not provide a comment. This figure went up to $15.3 \%$ in S2. Without the influence of the publicity and ceremony of the Unknown Warrior's return it seemed fewer visitors to the NWM were inclined to expand on their experience or express their feelings.

In conclusion, analyses of the NWM visitor comment samples revealed several insights into visitor interpretation and the construction of meaning. Both samples of visitor entries are, to varying degrees, connected to ideas of place, family and ritual. The NWM has the ability to trigger emotional responses in visitors, who find meaning in the design and atmosphere of the memorial landscape. These meanings are influenced by the life experiences visitors bring with them rather than inherent messages waiting to be 'discovered' by an audience. This results in different visitor interpretations. Entries identifying soldier ancestors and expressing the sense of debt owed to war dead construct a shared narrative of remembrance that is juxtaposed by personal statements about the futility of war and the need for peace. Differences in the frequency of entries in each sample period revealed the impact that social and historical conditions had on visitor experience. The prevalence of comments about the Unknown Warrior immediately following his interment highlights the popular reaction to the TUW project and its associated ceremonies. This is especially true for Pākehā New Zealanders who found collective meaning in a ritual they associated with their European heritage.

The association of place, family, and ritual with contemporary war remembrance is also evident in the answers of survey respondents to questions about the significance of the TUW. The following section considers how respondents employ a combination of collective national narrative and personal experience to form their interpretations of the TUW. Respondents also expand on the importance of New Zealand military ancestors in forming connections to the Unknown Warrior and how the design of the TUW added value to visitors' sense of place and ritual. 


\section{Visitor surveys}

In an effort to assess the reception of visitors to the TUW I administered a ninequestion survey to $20 \mathrm{New}$ Zealanders visiting the NWM. The survey contained basic demographic questions (including sex, age, place of residence, and ethnicity); and several structured questions to assess the frequency of the respondent's visit and whom they visited with. The survey also included four open-ended questions about visitors' perceptions of the TUW:

- Until 2004 New Zealand's war dead were represented by the Tomb of the Unknown Warrior in Westminster Abbey in London, England. How important do you think it is for New Zealand to have its own Tomb of the Unknown Warrior?

- Almost every New Zealand town or city has its own war memorial dedicated to their citizens who perished in various wars. What is the significance of the Tomb of the Unknown Warrior to you?

- The Tomb of the Unknown Warrior contains the remains of an unknown New Zealand soldier killed in France during the First World War. What or who does the Unknown Warrior represent to you?

- Could you identify what you like the most and what you dislike the most about the design of the Tomb of the Unknown Warrior?

The questions were based on the key themes and messages identified by $\mathrm{MCH}$ during the TUW project, 2002-2004. Respondents were asked for their thoughts and opinions on the importance of having a TUW to New Zealand society; what the TUW represented to them; and whether it had any personal significance to them. 


\section{The visitor sample}

The survey was conducted at the NWM over a three-month period 29 April 29 July 2009. During this time I employed a systematic research timetable in which I conducted two two-hour periods of visitor research per week. These took place twice a week on weekdays and weekends in the morning and afternoon (see Appendix 2).

My survey process was straightforward. I approached visitors as they left the NWM, explained the nature of my research and asked them if they would like to complete a short survey. If they agreed then the survey was completed immediately in the NWM foyer during a short five to ten minute interview. Responses were solicited from New Zealand citizens only as I was interested in national views and opinions of the TUW rather than international perspectives. As mentioned previously I selected visitors using a systematic interval sampling method of one visitor per thirty-minute period. This interval ratio was adopted in order to randomise interviewee selection.

In the end 20 visitors to the NWM completed my survey. The refusal rate was zero. The age range of my sample was $18-94$ years old. The mean age of my respondents was 44 years old and the median age 51 years old. There was roughly an even number of males (11/20) and females (9/20). Eighteen respondents identified themselves as New Zealand European or Pākehā, while the remaining two visitors I surveyed were naturalised New Zealanders originally from the United Kingdom. ${ }^{10}$ Over half of the visitors lived outside Wellington (12/20), while the others resided in either Wellington city (6/20) or the greater Wellington region $(2 / 20)$. The majority of visitors either came alone (9/20) or with a partner or spouse (4/20). In terms of visitation history, over half of the respondents were visiting the TUW for the first time $(12 / 20)$.

\footnotetext{
${ }^{10}$ One was originally from Scotland and the other from England.
} 


\section{The importance of the TUW for New Zealand}

Almost all respondents believed that it was important for New Zealand to have repatriated the remains of its own Unknown Warrior. The majority of responses were very nationalistic and questioned the relevance of having the British Unknown Warrior in Westminster Abbey represent New Zealand's war dead.

Having our own TUW is very important. I'm a republican and I think we should have our own head of state and our own identity split from Britain. The return of the Unknown Warrior helps us reach that (Male, 67)

Returning our own Unknown Warrior is very important so New Zealand has its own identity/symbol. Good for New Zealand to have its own unknown warrior here rather than in a foreign country (Female, 62)

It's really important to have the Unknown Warrior here in New Zealand. It seems illogical to have it in a country that most New Zealanders will never visit. It's more for people today than the soldiers lying in cemeteries overseas (Male, 32)

The return of the Unknown Warrior and the creation of the TUW were seen as a mark of New Zealand's progress since the world wars and the days of the British Empire.

The TUW is very important. It gives New Zealand ownership. Matter of respect and so the people of New Zealand are made aware of the sacrifices made. If it's in Westminster it's not New Zealand taking responsibility (Male, 62)

Sign of political maturity. New Zealand and the United Kingdom are going separate ways. New Zealand has fought in campaigns that the United Kingdom was not involved in i.e. Vietnam (Male, 51)

For some respondents the importance of returning an unknown warrior to New Zealand was couched in more practical terms and involved issues of accessibility and publicity. 
The TUW is terribly important. It's symbolically important to return our war dead separate to Britain. It's an accessibility issue. New Zealanders now have a place to come to in NZ to honour our unknown war dead. Not all of us have the means or opportunity to visit Westminster Abbey (Male, 25)

Good. Gives the NWM more significance and looks good. Helps publicise the NWM and all those soldiers who don't have a name on their headstones (Male, 18)

Only one respondent questioned the need to bring an Unknown Warrior back to New Zealand. This was on the basis that his remains had been lying undisturbed for nearly ninety years and the fact that it could not be proved unequivocally that he was a New Zealander.

I'm not sentimental in that respect. I've had family members serve in the New Zealand Wars, at Gallipoli and in WW2. It brings home the futility of war. The fact is he was resting in peace and has now been brought back thousands of miles to his country of origin - if indeed this is his country of origin (Male, 72)

\section{Significance of the TUW for visitors}

For most respondents the significance of the TUW was as a focal point for war commemoration. The TUW's location in Wellington helped centralise national war remembrance geographically and politically by providing an appropriate memorial from which to commemorate important national military anniversaries such as Anzac Day.

The location [of the TUW] is significant as Wellington is the capital (Male, 18)

The TUW is a focal point for commemoration and centralises remembrance. It is a national memorial (Female, 94)

Respondents suggested that the New Zealand Government's involvement in the return of the Unknown Warrior and construction of the TUW ensured that memorial had significant 'credibility and gravitas'. This status had been reinforced by the media 
coverage of the Unknown Warrior's arrival in New Zealand and the Armistice Day interment ceremony.

The TUW provides a place for national recognition. I watched the [televised] service and was touched by the sand from different parts of New Zealand being interred with remains, and I'm not an army or military buff at all (Male, 58)

It's a central place in the middle of New Zealand and the capital. The fact that its here in the place I live. If I were still living in Auckland I don't know if it would be as significant to me. The TUW has also been through a government process, which gives it credibility and a certain gravitas. This doesn't mean that smaller [war] memorials aren't equally important. The TUW represents the national, the smaller ones the local (Male, 25)

The fact that the TUW contains human remains was an important fact for several respondents. For these visitors the TUW was a grave where visitors could mourn the loss of family, however distant.

The TUW is different from other war memorials in New Zealand but not more important. It's significant because of its location and the fact that there are human remains inside (Male, 67)

The TUW represents my family members who are all buried overseas. The Tomb is a grave and is more about mourning rather than remembrance. You can walk past a cenotaph and it is about memory whereas the Tomb is much more personal because of the fact that it is a body inside. There is a greater sense of wairua [spirituality] because the Tomb has mauri [life force] (Female, 23)

For others the location of the TUW was not as significant. This was due to a lack of personal connection with the TUW. For some respondents their local war memorial provided a more palpable link to relatives or family acquaintances because they could read the names of their soldier-ancestors.

The TUW is a gathering place to remember the people that sacrificed their lives. I go to the Anzac service in Tirau. The names have had a great impact on me. They are local people and I know their descendents (Male, 54) 
It doesn't have the same impact. Where we are from Wanganui the name of one of our relations is on a memorial stone near the war memorial. We have more of a connection to that than the TUW, which is more remote (Male, 72)

\section{Visitor interpretation of the Unknown Warrior}

The majority of respondents did not express any close personal connection to the Unknown Warrior. He was viewed as a purely symbolic representation of New Zealand's war dead buried overseas.

The TUW is purely symbolic, although it does bring back memories of our ancestors who have fought in wars (Male, 58)

It's a symbol. I'm surprised it hasn't always been here (Female, 62)

Any personal connections respondents made with the Unknown Warrior seemed to be dictated by the existence of New Zealand military ancestors; especially ancestors who had died during wartime and were buried overseas. In other words, the Unknown Warrior was seen as a far more tangible figure for those who had lost family, however distant, during war.

I don't associate my relatives with the Unknown Warrior because they didn't die. Not the same form of remembrance as those who lost family (Male, 72)

Even though I don't know him or am not related to him I feel sad because he [Unknown Warrior] is representative of thousands of others. No personal connection. I had a great-grandfather who died during WW1 but he has a marked grave (Female, 32)

The Unknown Warrior represents all servicemen and women who served in NZ and abroad not those who stayed to keep the home fires burning. I have family members who have served in wartime but they are English. I'm a first generation New Zealander. I don't really connect them with here (Male, 25)

For others the family connection with the Unknown Warrior was more palpable. 
I had a brother who served in the Royal New Zealand Air Force and was killed in Britain. My husband also served but came home. Our family has a military background. My father was a professional soldier who fought at Gallipoli (Female, 94)

The Unknown Warrior represents my family and every single soldier who didn't come home (Female, 23)

For those remembering family members, place also played an important part in forming perceived connections with the Unknown Warrior.

No personal connection here. That would be the Auckland War Memorial Museum. I was taken there when I was young and saw my Great-Grandfather's name on the wall. Seeing his name provided more of a connection (Female, 20)

\section{The TUW design}

The majority of respondents appreciated the simplicity of the TUW design. The design was modern yet understated, and did not glorify war unlike the grand and obtuse memorials of the past. This helped the TUW integrate harmoniously with the surrounding NWM.

The Tomb is a simple classical shape. No pretence to glory (Male, 51)

I like its simplicity. The design is uncluttered and understated. It doesn't glorify war. The slight raise in the bronze lid is different and unique to this place (Male, 58)

Centre stage out front, not hidden inside or out back. The materials it's made out of will stand the test of time. The black colour and size [of the Tomb] represents all instead of one (Female, 34)

It's integration with the steps and entrance. A simple, centred, and contemporary take on a classical shape. I like the use of the tukutuku panels as crosses (Male, 42) 
There were references to materials and symbolism used on the TUW but few were overly nationalistic. Respondents seem especially drawn to the inscriptions on the TUW.

I like the written karanga; the pounamu crosses and the materials used. I also like the shape and the juxtaposition between the marble and bronze. Its position in the stairs means that the Tomb is part of the NWM (Female, 23)

The design is typically Kiwi. Not loud at all. It is unassuming yet powerful, and all black (Male, 62)

The inscriptions make you want to touch it [the Tomb]. I like the effect the rain has on the surface (Female, 30)

Only a small number of respondents expressed criticism of the TUW's design. Some felt the TUW was too simplistic and offered no visual impact. Some visitors felt there was distinct lack of pomp and pageantry associated with the TUW, especially compared to overseas Unknown Soldier tombs. Other respondents had more practical concerns about the exposed location of the TUW and the lack of protection against human interference.

Although I don't like to look at the TUW in a critical light you could pass it without seeing it. I don't think it's noisy enough. You need to draw people to it (Male, 62)

The lid looks like a BBQ top - it's also discoloured. The Tomb is modern while the rest of the NWM is old. No eternal flame. It's underwhelming compared to the rest of the world (Female, 67)

There are no skate stoppers. These could have been integrated into the design. Five years on we still have skateboarders using it as a plaything - and they seem to be getting younger. Design important but we have to think about the Tomb's longevity (Female, 23)

Other respondents were confused with elements of the TUW's symbolism, especially the crosses, which seem too universal and not 'Kiwi' enough.

The crosses seem ambiguous (Female, 20) 
Not a fan of the crosses. They don't symbolise anything to me. Not offensive though (Male, 58)

The white crosses don't look very New Zealand to me (Male, 67)

\section{Conclusion}

The aim of this dissertation was to examine visitor interpretations of the TUW and analyse these in the light of the institutional objectives set out in its design and planning, and the political and popular motivations that led to its construction. I drew on entries left in the NWM visitor books and onsite survey interviews with visitors to access audience understandings of, and responses to, the Unknown Warrior and the TUW memorial. These methods provided access to subjective visitor insights, drawing on developments in the fields of public history and visitor research studies, to explore the active meaning-making of audiences and ability of visitors to derive multiple interpretations from historic and heritage sites such as the TUW.

The findings that emerge from this visitor research illustrate how visitors to the NWM draw on a combination of public and private narratives to construct meanings from the TUW. These narratives relate to aspects of public ritual, national identity, and personal connections. Visitor interpretations of the TUW were, to a large extent, influenced by public ritual. This is evident in the influx of New Zealand visitors to the NWM and the frequency of visitor entries related to the Unknown Warrior immediately following his interment compared to three years later. The return of the Unknown Warrior was one the largest public ceremonial events ever held in New Zealand. New Zealanders, more especially Pākehā New Zealanders, were particular receptive to these ceremonies because they had roots in their European heritage. The burying of an Unknown Warrior was a civic ritual tied to the concept of citizenship that emerged in classic Greek and Roman states. The return of the Unknown Warrior, the military procession through Wellington, and his interment in the TUW allowed Pākehā to establish a sense of community and continuity with the past. 
The popular reaction of Pākehā New Zealanders to these ritual elements overlaps with the official objectives of the TUW project. These revolved around the maintenance of national identity and establishing a continuity of the past and present in regards to social cohesion. The TUW represented a focal point for national remembrance of the nation's war dead; a symbol of unity and national identity, which linked generations of New Zealanders. The popular reception given to the Unknown Warrior suggests that the connection between war history and national identity remains significant, and the 'cult of the fallen soldier' described by George Mosse (1990) continues to maintain its appeal in the twenty-first century, albeit in a different form.

The TUW represents the intersection of individual memory, civil remembrance and national commemoration. Visitor response to the TUW shows how the subjectivity of individual memory is constructed through practices of local and national commemoration. The fact that these visitors are drawing on aspects of public and private memory supports popular memory theory (Misztal 2003, Thomson 1994) which suggests that individual remembering always invokes broader public discourses and that personal accounts of the past are never produced in isolation from public narratives. These dynamics are evident in my visitor surveys, in which respondents drew on elements of national narrative and personal experience in their responses. Visitors bring with them the histories and ritual traditions of local war memorials. Some find more significance in local or regional war memorials than the TUW because of the presence of names of relatives or family acquaintances on them, and the fact that these are the sites they associate with annual commemorative rituals such Anzac Day. This demonstrates how the interpretations of visitors are dictated by personal histories, and the construction of meaning rests on linkages influenced by aspects of lived experience and family history. This affects the connection people make with the TUW as a place and the Unknown Warrior as an individual. For visitors, personal connections with the Unknown Warrior depend on the existence of New Zealand military ancestors who died during wartime and were buried overseas. 
Social and historical conditions have also impacted on visitor interpretations of the TUW. Contemporary war commemoration in New Zealand takes place in a post military society (Shaw 1997). War and national security issues have largely diminished in New Zealand and the nature of modern warfare will most likely never see New Zealand mourning loss of life on the scale of the world wars again. This is one of the reasons why 'grassroots' support for war remembrance continues to remain strong (Clarke 2008). War is a foreign concept for recent generations of New Zealanders yet its influence is present throughout modern-day New Zealand society in our war memorials, public rituals, and war history literature and projects.

For visitors to the NWM, the presence of the TUW adds to their sense of national identity. The repatriation of our own Unknown Warrior and establishment of the TUW are examples of our autonomy and a mark of the progress we had made since the days of the British Empire. As such they fit into a popular narrative of New Zealand independence. The TUW provides the opportunity to remember and honour the experience of New Zealand soldiers, which were different from those of Great Britain. Visitors considered it only right that we had own Unknown Warrior rather having the Westminster Abbey Tomb as a proxy national memorial.

The remembrance space has widened. The bi-cultural elements of national remembrance were very evident in the planning of the TUW and the ceremonial aspects of the Unknown Warrior's repatriation from France. They are also very evident in the language and design of the Tomb. The Unknown Warrior represents a narrative of shared experience for Māori and Pākehā, and represents the sacrifice of both communities. Yet this is also a narrative that continues to omit important parts of New Zealand's war history. There continues to be no room for the commemoration of the New Zealand Wars at the NWM, where the focus of remembrance remains exclusively on commemorating New Zealand's contribution to overseas wars. In the meantime our internal civil wars remain on the periphery of collective memory. The chapter of history they represent does not fit comfortably with our prescribed cultural nationalism and they continue to be ignored. 
I am aware, however, that this dissertation is very much a New Zealand Pākehā perspective. Māori were evident in the visitor book entries but they were absent from my visitor survey sample. This is a significant limitation for the research as it would be valuable to know the perspective of Māori in relation to the Unknown Warrior, and war remembrance in general, especially with regard to their treatment of the dead, which varies amongst iwi. As we have seen individual memories are the product of group communication and the collective memory of the community. Future studies working within community groups could provide valuable insights into the ways in which stories about the past are handed down within families, or circulate amongst friends. Like Alistair Thomson's (1994) study of the Anzac legend in Australia, this community-based work would enable us to see how the interpretations of these communities compare to historical representations that circulate on a wider scale through towns, regions, the nation and the mass media. This would not only be valuable in studying Māori and Pākehā perspectives but also New Zealanders from other ethnic backgrounds. After all, the Tomb is for all New Zealanders and the space of war remembrance is not just bi-cultural. In 2008 the NZRSA national secondary schools speech competition was won by Raphael Mobegi, a Kenyan migrant whose speech addressed the meaning of New Zealanders' service and sacrifice throughout our history.

The current study has illustrated the gradual development of the NWM site and the impact that social and historical conditions have had on the interpretations of visitors. Future research could build on this by examining the impact of further changes to this site. The Government has committed to building a memorial park adjacent to the NWM, which will impact on the visitor experience. How will visitors interact with this new space and how will it affect their interpretation of the TUW and NWM?

This dissertation provides a contemporary snapshot which moves past political and social agency theory to show the popular memory of New Zealand's war remembrance. It shows how memory is historically evolving and contingent. Events 
such the creation of the TUW, along with annual commemorations such as Anzac Day, and anniversaries commemorating key military events maintain the profile and impetus of war remembrance and commemoration in New Zealand. Yet this is a national narrative that neither promotes the sacrifice of its citizens nor is driven by the grief of the bereaved. The popular memory of visitors to the NWM is influenced by a narrative of war remembrance formed in a post-military society, in which the emphasis is on understanding the human experience of war rather than grief or promoting the ideal of sacrifice or service. The anonymity of the Unknown Warrior provides visitors with a link into family history and the TUW provides a focal point for remembrance that is reinforced by associated rituals of commemorative events such as Anzac Day, Armistice Day and various anniversaries of wars. 


\section{Appendix 1: The Visitor Survey}

\section{Tomb of the Unknown Warrior Visitor Survey}

Survey No

Age
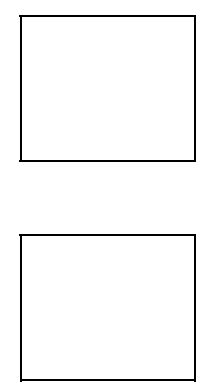

Date

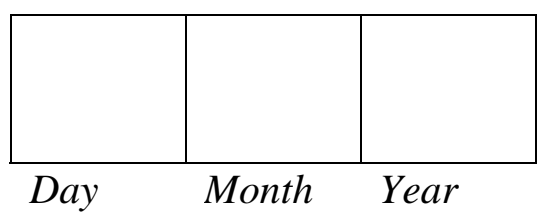

Male

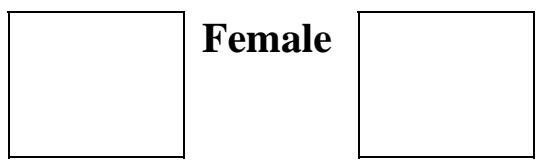

1. Until 2004 the Tomb of the Unknown Warrior in Westminster Abby represented New Zealand's war dead. How important do you think it is for New Zealand to have its own Tomb of the Unknown Warrior? 
2. Almost every New Zealand city or town has its own war memorial dedicated to its citizens who perished in conflict. What is the significance of the Tomb of the Unknown Warrior to you?

\begin{tabular}{|l|}
\hline \\
\hline \\
\hline \\
\hline \\
\hline \\
\hline \\
\hline \\
\hline \\
\hline
\end{tabular}


3. The Tomb of the Unknown Warrior contains the remains of an unknown New Zealand soldier killed in France during the First World War. What or whom does the Unknown Warrior represent to you?

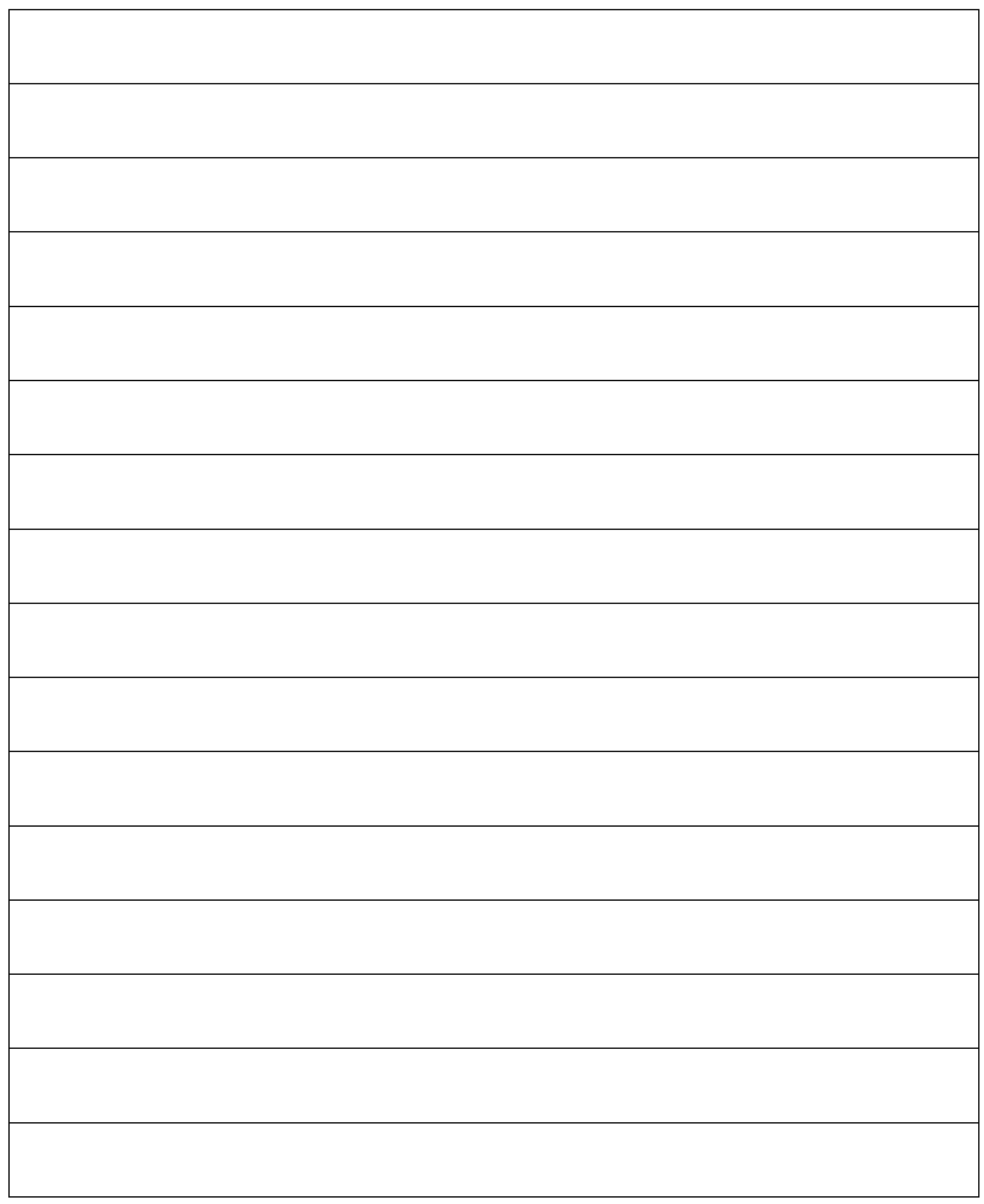


4. Could you identify what you like the most and what you dislike the most about the design of the Tomb of the Unknown Warrior?

\section{Liked the most:}

Disliked the most: 
5. Is this your first visit to the Tomb of the Unknown Warrior

Yes

No

2

6. How many times - not counting today - have you visited the TUW in the last 12 months?

7. Who did you visit the TUW with today?

Alone

With my partner/spouse

2

With an organised tour

With (a) friend/s

4

With a family member or family group

5

With an educational group

6

Other (Please specify below) 
8. Where do you usually live?

In Wellington City

Please specify suburb:

In Wellington Region

2

Please specify town or city:

Outside Wellington region but in NZ

Please specify town or city:

\section{Which ethnic group(s) or nationality do you identify with?}

NZ Māori (list Iwi affiliation if known) 1

NZ European 2

Pacific Island 3

$\begin{array}{ll}\text { Asian } & 4\end{array}$

Other (specify) $\quad 5$ 


\section{Appendix 2: NWM Visitor Research Timetable}

I conducted visitor research at the National War Memorial (NWM) two days per week for a period of three months (29 April - 29 July 2009). Each day comprised a two-hour period of visitor research, which started either in the morning (1100-1300) or afternoon (1400-1600). The opening hours of the NWM are Monday to Saturday 1030 - 1630, and Sunday 1200 - 1630. The details of my research timetable are below:

\begin{tabular}{|c|c|c|c|c|c|c|}
\hline \multicolumn{7}{|c|}{ April 2009} \\
\hline $\mathbf{M}$ & $\mathbf{T}$ & $\mathbf{w}$ & $T$ & $\mathbf{F}$ & S & s \\
\hline & & 1 & 2 & 3 & 4 & 5 \\
\hline 6 & 7 & 8 & 9 & 10 & 11 & 12 \\
\hline 13 & 14 & 15 & 16 & 17 & 18 & 19 \\
\hline 20 & 21 & 22 & 23 & 24 & 25 & 26 \\
\hline 27 & 28 & 29 & 30 & & & \\
\hline
\end{tabular}

\begin{tabular}{|c|c|c|c|c|c|c|}
\hline \multicolumn{7}{|c|}{ May 2009} \\
\hline $\mathbf{M}$ & $T$ & $\mathbf{W}$ & $\mathbf{T}$ & $\mathbf{F}$ & $S$ & $\mathbf{S}$ \\
\hline & & & & 1 & 2 & 3 \\
\hline 4 & 5 & 6 & 7 & 8 & 9 & 10 \\
\hline 11 & 12 & 13 & 14 & 15 & 16 & 17 \\
\hline 18 & 19 & 20 & 21 & 22 & 23 & 24 \\
\hline 25 & 26 & 27 & 28 & 29 & 30 & 31 \\
\hline
\end{tabular}

\begin{tabular}{|c|c|c|c|c|c|c|}
\hline \multicolumn{7}{|c|}{ June 2009} \\
\hline $\mathbf{M}$ & $\mathbf{T}$ & $\mathbf{W}$ & $\mathbf{T}$ & $\mathbf{F}$ & $\mathrm{s}$ & $S$ \\
\hline 1 & 2 & 3 & 4 & 5 & 6 & 7 \\
\hline 8 & 9 & 10 & 11 & 12 & 13 & 14 \\
\hline 15 & 16 & 17 & 18 & 19 & 20 & 21 \\
\hline 22 & 23 & 24 & 25 & 26 & 27 & 28 \\
\hline 29 & 30 & & & & & \\
\hline
\end{tabular}

\begin{tabular}{|c|c|c|c|c|c|c|}
\hline \multicolumn{7}{|c|}{ July 2009} \\
\hline $\mathbf{M}$ & $\mathbf{T}$ & $\mathbf{W}$ & $\mathbf{T}$ & $\mathbf{F}$ & $S$ & $S$ \\
\hline & & 1 & 2 & 3 & 4 & 5 \\
\hline 6 & 7 & 8 & 9 & 10 & 11 & 12 \\
\hline 13 & 14 & 15 & 16 & 17 & 18 & 19 \\
\hline 20 & 21 & 22 & 23 & 24 & 25 & 26 \\
\hline 27 & 28 & 29 & 30 & 31 & & \\
\hline
\end{tabular}

AM: $1100-1300$

PM: 1400 - 1600 


\section{Appendix 3: Information Sheet}

\section{TI WHARE WANANCA O TY DPOKO O TE IKA A MAXU

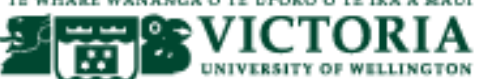 \\ Information Sheet Tomb of the Unknown Warrior Visitor Survey}

Researcher: $\quad$ Gareth Phipps, School of Art History, Classics \& Religious Studies Victoria University of Wellington

I am a Masters student in the Museum \& Heritage Studies programme at Victoria University of Wellington. As part of my degree I am undertaking a research dissertation focused on the Tomb of the Unknown Warrior (TUW). The broad aim of this project is to compare the meanings and memories of war remembrance represented in the TUW with the interpretations of visitors to the site.

As part of this project I am conducting a survey of visitors to the TUW at the National War Memorial in Wellington. Visitors will be asked to complete a short survey in regards to their visit. The survey will establish a profile of respondents in terms of age, sex, place of origin and invite them to answer nine questions relating to demographics, visitation history, and personal perceptions of the TUW. It is envisaged that the survey will take no more than fifteen minutes to complete.

I plan to include information collected from these visitor surveys in my dissertation. Any survey material used will be presented anonymously. Only the age and place of origin of survey respondents will be published.

All survey material will be kept confidential. The surveys will be deposited in a locked file and access will be restricted to my academic supervisor and me.

If you have any questions or would like to receive further information about the project, please contact me at gareth.phipps@vuw.ac.nz or my academic supervisor, Dr Lee Davidson, at Victoria University of Wellington, PO Box 600, Wellington, phone +64 4463 5929, email lee.davidson@vuw.ac.nz.

Gareth Phipps

Student researcher 


\section{Bibliography}

Anderson, Benedict. 1991. Imagined Communities: Reflections on the Origin and Spread of Nationalism. London \& New York: Verso.

-1991. Imagined Communities: Reflections on the Origins and Spread of Nationalism. London \& New York: Verso.

Andriotis, Konstantinos. 2009. Sacred Site Experience: A Phenomenology Study. Annals of Tourism Research 36 (1):64-84.

Ashplant, Timothy G., Graham Dawson, and Michael Roper, eds. 2004. The Politics of Memory: Commemorating War. New Brunswick \& London: Transaction.

Atkinson, Neill, ed. 2005. Hell or High Water: New Zealand Merchant Seafarers Remember the War. Auckland: HarperCollins.

Baird, Kingsley. 2008. The Tomb of the Unknown Warrior Te Toma o Te Toa Matangaro 2004 [cited 30 July 2008]. Available from http://www.kingsleybaird.com/index.php?sid=5.

Barry, Maggie. 2007. At Peace with the Past. New Zealand Listener, April 28 - May 4 2007.

Borg, Alan. 1991. War Memorials from Antiquity to the Present. London: Leo Cooper.

Boyack, Nicholas, and Jane Tolerton, eds. 1990. In the Shadow of War: New Zealand Soldiers Talk About World War One and Their Lives. Auckland: Penguin Books.

Buchanan, Rachel. 2007. The Dementia Wing of History. Cultural Studies Review 13 (1):173-186.

Butterworth, Susan. 2003. National War Memorial. Phanzine 9 (2):4.

Callister, Sandy. 2008. The Face of War: New Zealand's Great War Photography. Auckland: Auckland University Press.

Challinor, Deborah. 1998. Grey Ghosts: New Zealand Vietnam Vets Talk About Their War. Auckland: Hodder Moa Beckett.

Clarke, Stephen. 2008. ANZAC Day in Aotearoa: Yesterday, Today, Tomorrow. Paper read at War and Remembrance conference, 2 May, at The Stout Research Centre, Victoria University of Wellington. 
Clifford, James. 1997. Routes: Travel and Translation in the Late Twentieth Century. Cambridge: Harvard University Press.

Damousi, Joy. 2001. Living with the Aftermath: Trauma, Nostalgia and Grief in PostWar Australia. Cambridge: Cambridge University Press.

Elliot, Barbara Jane. 2005. Using Narrative in Social Research: Qualitative and Quantitative Approaches. Thousand Oaks and London: Sage.

Forest, Benjamin, and Juliet Johnson. 2002. Unravelling the Threads of History: Soviet-Era Monuments and Post-Soviet National Identity in Moscow. Annals of the Association of American Geographers 92 (3):524-547.

Fussell, Paul. 1975. The Great War and Modern Memory. London and New York: Oxford University.

Gibbs, Graham. 2007. Analyzing Qualitative Data. London \& Thousand Oaks: Sage.

Glaser, Barney, and Anselm Strauss. 1967. The Discovery of Grounded Theory. Chicago: Aldine.

Glassberg, David. 1996. Public History and the Study of Memory. The Public Historian 18 (2):7-23.

Green, Anna. 2004. Individual Remembering and Collective Memory: Theoretical Presuppositions and Contemporary Debates. Oral History 32 (2):35-44.

Halbwachs, Maurice. 1992. On Collective Memory. Translated by L.A. Coser. Chicago: University of Chicago Press.

Hass, Kristin Ann. 1998. Carried to the Wall: American Memory and the Vietnam Veterans Memorial. Berkeley and London: University of California Press.

Hobsbawm, Eric, and Terence Ranger, eds. 1983. The Invention of Tradition. Cambridge: Cambridge University Press.

Hon. William Jennings. 1921. Burial of Unknown New Zealand Warrior. In New Zealand Parliamentary Debates. 192. Wellington: Marcus F. Marks Government Printer.

Hooper-Greenhill, Eilean. 2006. Studying Visitors. In A Companion to Museum Studies, edited by S. Macdonald. Malden: Blackwell.

Human Ethics Committee. 2003. Human Ethics Policy. Victoria University of Wellington. 
Hunter, Kathryn. 2002. States of Mind: Remembering the Australian-New Zealand Relationship. Journal of the Australian War Memorial (36).

Hutching, Megan, ed. 2001. A Unique Sort of Battle: New Zealanders Remember Crete. Auckland: HarperCollins.

— ed. 2002. Inside Stories: New Zealand Prisoners of War Remember. Auckland: HarperCollins.

— ed. 2004. A Fair Sort of Battering: New Zealanders Remember the Italian Campaign. Auckland: HarperCollins.

— ed. 2005. The Desert Road: New Zealanders Remember the North African Campaign. Auckland: HarperCollins.

— War. Auckland: HarperCollins.

— ed. 2007. Last Line of Defence: New Zealanders Remember the War at Home. Auckland: HarperCollins.

Inglis, Ken. 1998. Sacred Places: War Memorials in the Australian Landscape. Melbourne: Melbourne University Press.

King, Alex. 1998. Memorials of the Great War in Britain: The Symbolism and Politics of Remembrance. Oxford: Berg.

Kippenberger, H. K. to Hon. W. A. Bodkin. 15 December 1950. National War Memorial.

Lloyd, David. 1998. Battlefield Tourism: Pilgrimage and Commemoration of the Great War in Britain, Australia, and Canada 1919-1939. Oxford: Berg.

Lowenthal, David. 1985. The Past is a Foreign Country. Cambridge: Cambridge University Press.

Macdonald, Sharon. 2005. Accessing Audiences: Visiting Visitor Books. Museum and Society 3 (3):119-136.

- 2006. Expanding Museum Studies: An Introduction. In A Companion to Museum Studies, edited by S. Macdonald. Malden: Blackwell.

Maclean, Chris, and Jock Phillips. 1990. The Sorrow and the Pride: New Zealand War Memorials. Wellington: Historical Branch, Department of Internal Affairs. 
Marshall, Debra. 2004. Making sense of remembrance. Social \& Cultural Geography $5(1): 37-54$.

Masberg, Barbara, and Lois Silverman. 1996. Visitor Experiences at Heritage Sites: A Phenomenological Approach. Journal of Travel Research 34 (20):20-25.

Matthews, Martin to Minister for Arts Culture and Heritage. 11 December 2001. Tomb of the New Zealand Unknown Warrior, BR2001/482.

to Minister for Arts Culture and Heritage. 7 May 2002. Tomb of the Unknown New Zealand Warrior, BR2002/142.

to Minister for Arts Culture and Heritage. 18 November 2003. Tomb of the Unknown Warrior - Revised Plan, BR2004/475.

McGibbon, Ian to H. G. Acting General Manager. 11 November 1999. Repatriation of an Unknown Warrior.

_ 2001. New Zealand Battlefields and Memorials of the Western Front. Auckland: Oxford University Press.

Milne, Jonathan. 2003. PM's Plans for War Memorial Shock Historians. Sunday Star Times, 6 April.

Ministry for Culture and Heritage. 2003. Proposal for the Tomb of the Unknown Warrior: Conditions for the Design Selection Process.

- 2003. Tomb of the Unknown Warrior Project: Key messages/themes, HER $716 / 5$.

_. Ministry for Culture and Heritage 2005 Annual Report 2005 [cited 19 October 2007. Available from http://www.mch.govt.nz/publications/annual2005/tomb.html.

Misztal, Barbara A. 2003. Theories of Social Remembering. Maidenhead: Open University Press.

Mosse, George. 1990. Fallen Soldiers: Reshaping the Memory of the World Wars. Oxford: Oxford University Press.

Nathan, Simon. 2008. War Memorials 2008 [cited 19 June 2008]. Available from http://blog.teara.govt.nz/2008/04/23/war-memorials/.

Nightingale, Tony. 2003. Not So Sacred Ground - the National War Memorial. Phanzine 9 (1):4-5. 
Nora, Pierre, and Lawrence D. Kritzman. 1996-98. Realms of Memory: Rethinking the French Past. 3 vols. New York: Columbia University Press.

Phillips, Jock. 2005. The Quiet Western Front - The Great War and New Zealand Memory.

Reed, Liz. 2004. Bigger Than Gallipoli: War, History and Memory in Australia. Crawley: University of Western Australia Press.

Samuel, Raphael. 1994. Theatres of Memory. London: Verso.

Sarantakos, Sotirios. 2004. Social Research. Third ed. Basingstoke: Palgrave Macmillan.

Scates, Bruce. 2006. Return to Gallipoli: Walking the Battlefields of the Great War. Cambridge: Cambridge University Press.

Schouten, Hank. 2004. A Project 80 Years in the Making. Dominion Post, 11 November, G2.

Schutt, Russell K. 2006. Investigating the Social World: The Process and Practice of Research. 5th ed. Thousand Oaks: Pine Forge Press.

Shadbolt, Maurice. 1988. Voices of Gallipoli. Auckland: Hodder and Stoughton.

Shaw, Martin. 1997. Past Wars and Present Conflicts: From the Second World War to the Gulf. In War and Memory in the Twentieth Century, edited by M. Evans and K. Lunn. Oxford: Berg.

Sherman, Daniel J. 1999. The Construction of Memory in Interwar France. Chicago and London: The University of Chicago Press.

Shoebridge, Tim. 2009. National War Memorial \& Tomb of the Unknown Warrior. Wellington: Ministry for Culture and Heritage.

Thomson, Alistair. 1994. Anzac Memories: Living with the Legend. Melbourne: Oxford University Press.

Traue, Jim. 2005. Rituals for our Warrior. The Press, 10 January, 9.

Wengraf, Tom. 2001. Qualitative Research Interviewing: Biographical Narrative and Semi-structured Methods. Thousand Oaks and London: Sage.

Winter, Jay. 1995. Sites of Memory, Sites of Mourning: The Great War in European Cultural History. Cambridge: Cambridge University Press. 
Winter, Jay, and Antoine Prost. 2005. The Great War in History. Cambridge: Cambridge University Press.

Winter, Jay, and Emmanuel Sivan, eds. 1999. War and Remembrance in the Twentieth Century. Cambridge, New York: University of Cambridge.

Worthy, Scott. 2004. Communities of Remembrance: Making Auckland's War Memorial Museum. Journal of Contemporary History 39 (4):599-618.

Young, James E. 1993. The Texture of Memory: Holocaust Memorials and Meaning in Europe, Israel, and America. New Haven: Yale University Press. 